\title{
Ireland: 2009 Article IV Consultation-Staff Report; and Public Information Notice on the Executive Board Discussion
}

Under Article IV of the IMF's Articles of Agreement, the IMF holds bilateral discussions with members, usually every year. In the context of the 2009 Article IV consultation with Ireland, the following documents have been released and are included in this package:

- $\quad$ The staff report for the 2009 Article IV consultation, prepared by a staff team of the IMF, following discussions that ended on May 1, 2009, with the officials of Ireland on economic developments and policies. Based on information available at the time of these discussions, the staff report was completed on May 20, 2009. The views expressed in the staff report are those of the staff team and do not necessarily reflect the views of the Executive Board of the IMF.

- $\quad$ A Public Information Notice (PIN) summarizing the views of the Executive Board as expressed during its June 15, 2009, discussion of the staff report that concluded the Article IV consultation.

The policy of publication of staff reports and other documents allows for the deletion of market-sensitive information.

\author{
Copies of this report are available to the public from \\ International Monetary Fund • Publication Services \\ $70019^{\text {th }}$ Street, N.W. • Washington, D.C. 20431 \\ Telephone: (202) 623-7430 • Telefax: (202) 623-7201 \\ E-mail: publications@imf.org・Internet: http://www.imf.org
}

\section{International Monetary Fund \\ Washington, D.C.}





\section{INTERNATIONAL MONETARY FUND}

\section{IRELAND}

\section{Staff Report for the 2009 Article IV Consultation}

Prepared by the Staff Representatives for the 2009 Consultation with Ireland

Approved by Ajai Chopra and Martin Mühleisen

May 20, 2009

\section{Executive Summary}

Given its serious internal imbalances, Ireland was especially vulnerable to the recent global shocks. Overextension in construction and financial intermediation, along with loss of international competitiveness, has meant that the impact will be sizeable. Cumulatively, GDP is projected to contract by $13 \frac{1}{2}$ percent through 2010, the largest among advanced economies. Thereafter, as the present dislocations gradually correct themselves, only a modestly-paced recovery is foreseen. The incipient decline in wages will need to be sustained to help redress Ireland's cost disadvantage.

\section{Rapid progress on bank restructuring is critical to reestablishing a healthy financial} sector. With banks facing liquidity pressures and sizeable losses, the authorities have taken important steps to stabilize the financial system - through the blanket guarantee to depositors and creditors and the recapitalization of banks. ECB credit lines have provided valuable liquidity. The proposed National Asset Management Agency is potentially the right mechanism to separate the good from the bad assets. Its success requires a comprehensive and realistic assessment of impaired assets. The authorities' efforts to press ahead with supportive regulatory and supervisory measures will help manage the current stress and lower the risk of future crises.

Fiscal consolidation has begun - and requires a sustained effort. The authorities' sense of urgency is welcome. Such, however, has been the collapse of revenues that the 2009 deficit could reach 12 percent of GDP. The authorities recognize that the execution of their ambitious consolidation plan will require a continuing commitment to address sensitive expenditures, including the public wage bill and the scope of social welfare programs. The consolidation will be more credible the more tightly it is tied to monitorable goals. 


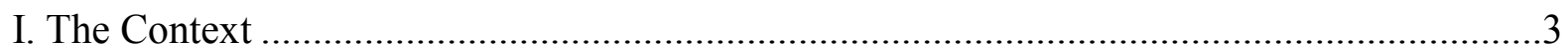

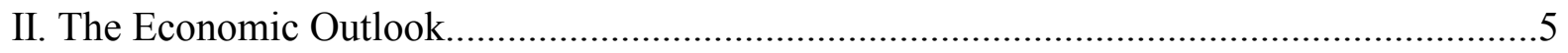

A. The Near-Term Dynamics....................................................................... 5

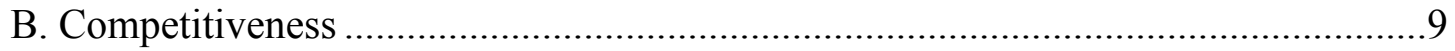

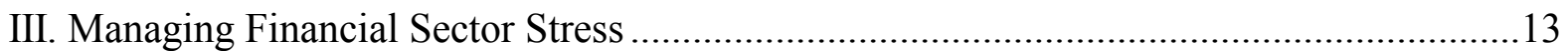

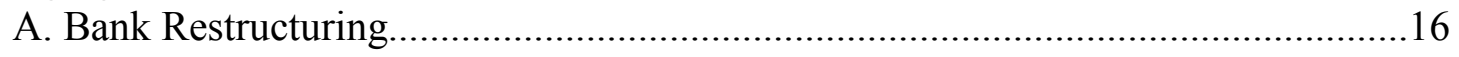

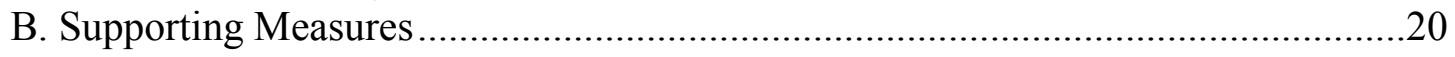

IV. Achieving Fiscal Credibility ..............................................................................2

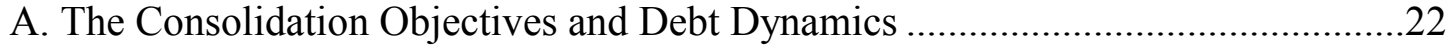

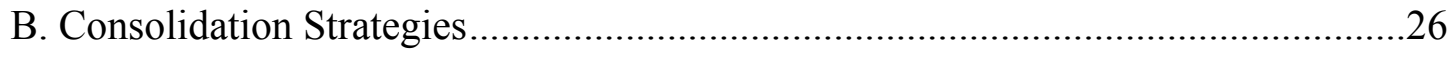

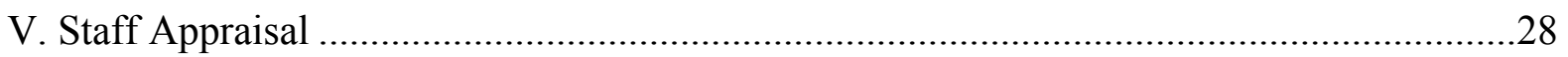

Tables

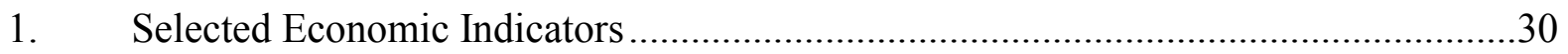

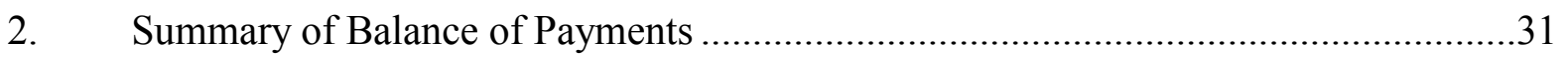

3. General Government Finances ............................................................................. 32

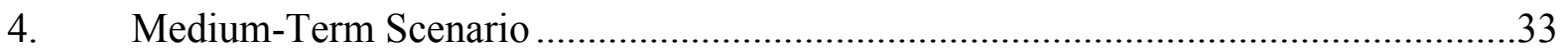

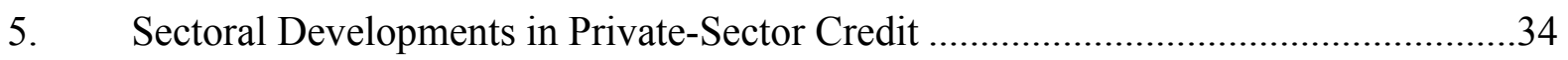

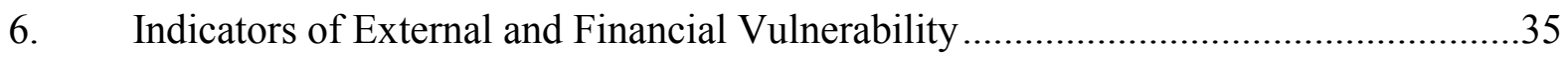

\section{Figures}

1. Exposures and Vulnerabilities ...........................................................................4

2. Competitiveness and Potential Output Growth...................................................... 10

3. Shares of Global and Eurozone Foreign Direct Investment......................................11

4. Ireland's Labor Cost and Price Levels Relative to the Eurozone ..............................12

5. Alternative Fiscal Scenarios.............................................................................25

\section{Boxes}

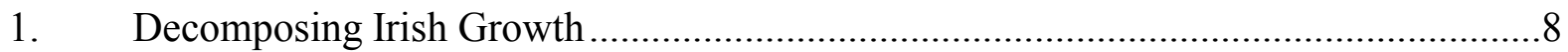

2. Financial Vulnerability, Public Finances, and Economic Growth .............................18

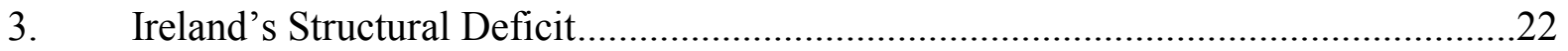

Appendix

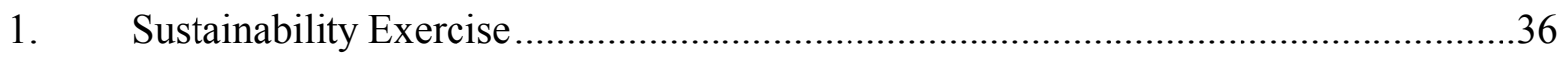




\section{THE CONTEXT ${ }^{1}$}

1. Ireland's ongoing painful adjustment reflects the unwinding of critical internal imbalances. Since the start of the decade, and especially from 2005 to 2007, easy credit fostered a property bubble, bank exposures to property lending soared while reliance on wholesale funding intensified, and international competitiveness was compromised as wages climbed rapidly. On all these dimensions, Ireland had become remarkably vulnerable (Figure 1). Yet, dazzling growth and buoyant public revenues prompted tax reductions and expansion of public expenditures that have proved unsustainable. Various commentators and the IMF in its Article IV consultations did warn that the seemingly-unstoppable growth masked serious imbalances, including the fragility of public finances.

\section{As the global turmoil has unfolded, Ireland has benefited from the safety} provided by its membership in the eurozone. This has allowed it to avoid the currency pressures that typically accompany financial crises. Moreover, access to ECB financing has been an important source of liquidity for the banking sector. However, since the possibility of adjusting through the depreciation of its own exchange rate is not available, further wage reductions will be required to restore competitiveness and growth prospects.

3. The Irish authorities have moved with resolve to counter the severe economic and financial shocks - that resolve will need to be sustained. Recognizing the vulnerabilities that rendered the economy particularly susceptible to the unprecedented events since the onset of the global financial crisis, the authorities have acted to contain the damage. At the same time, they have introduced initiatives to repair the financial and fiscal systems. To bear fruit, these efforts will require determined execution over several years. Robust policy instruments that allow the flexibility to deal with surprises and the self-discipline of transparent benchmarks will help stay the course.

\section{The priorities are clear:}

- Decisive efforts to restore healthy functionality of the financial sector are essential to prevent festering problems and an anemic economy.

- $\quad$ To be sustained, fiscal consolidation measures should be underpinned by a structure of rules and accountability within which politically-sensitive trade-offs can be made.

5. A continued search for pragmatic policy initiatives will be needed in the face of acute policy dilemmas. Financial support to banks is necessary but adds to the fiscal burden. Reducing fiscal deficits is needed to maintain credibility with markets but deepens the economic contraction. Expenditure reduction, as distinct from raising taxes, is the superior approach to fiscal consolidation but, unless carefully managed and prioritized, risks hurting the most vulnerable.

\footnotetext{
${ }^{1}$ The staff team comprised Mr. Mody (head), Mr. Kanda, Ms. Athanasopoulou (all EUR), Messrs. Seelig and Darbar (both MCM), and Ms. Luedersen (LEG), and visited Dublin during April 20-May 1, 2009.
} 
Figure 1. Ireland: Exposures and Vulnerabilities
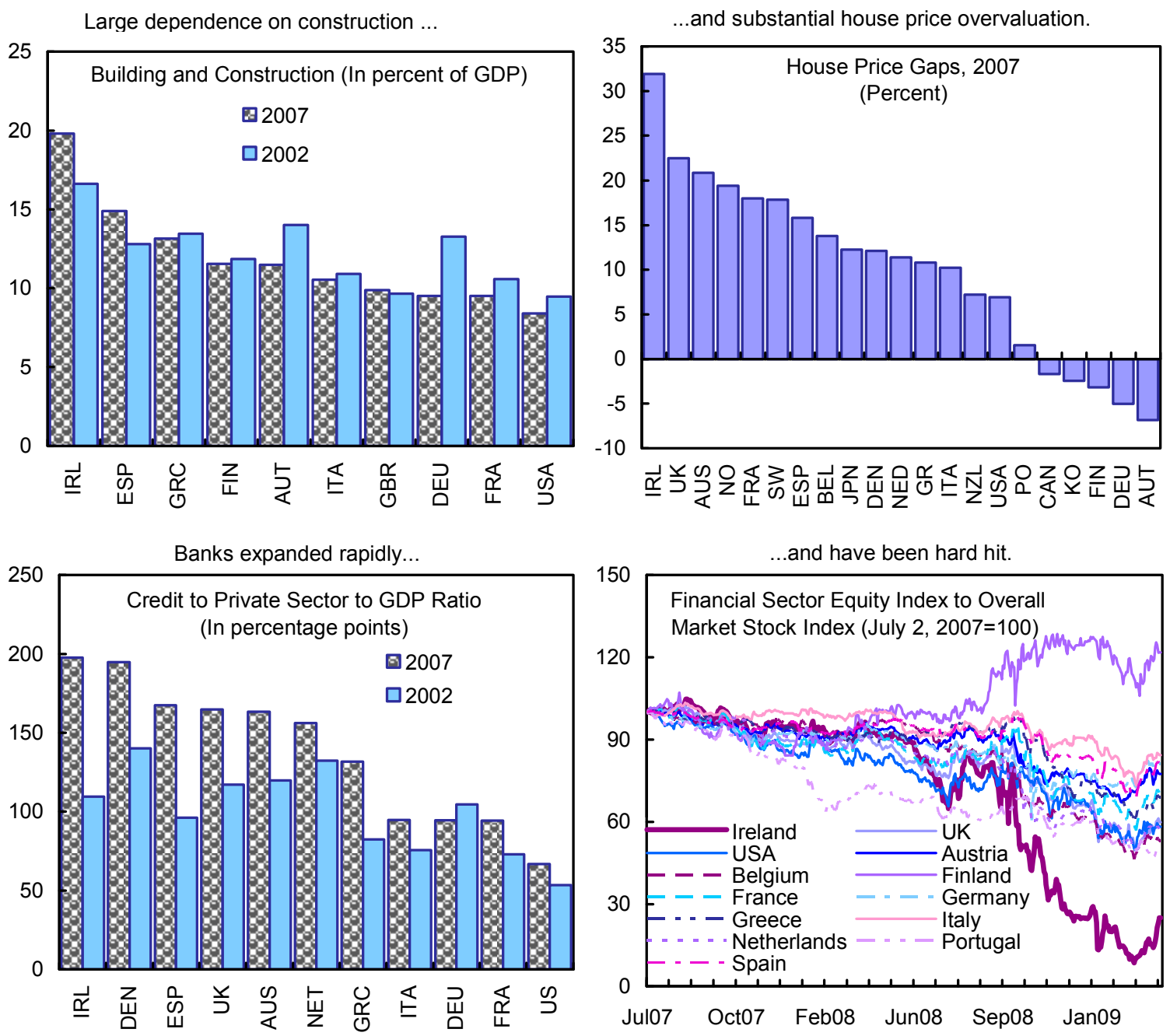

The economy is very open...
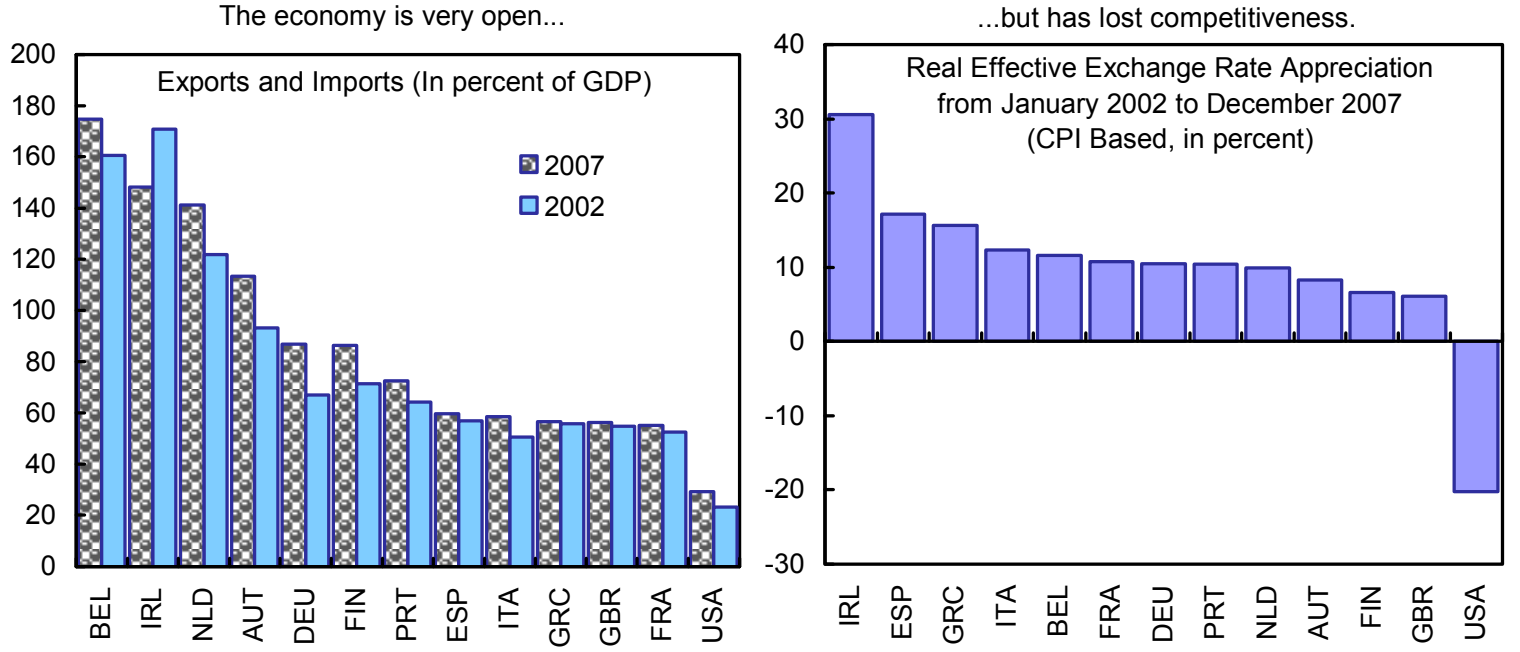

Sources: Thompson Financial/Datastream; and IMF, IFS and World Economic Outlook. 


\section{THE ECONOMIC OUTLOOK}

6. The economic contraction started in early 2008 and then rapidly accelerated. GDP grew at a brisk 6 percent in 2007. However growth began to slow with a deceleration in housing construction in early 2008, even while parts of the eurozone, notably Germany, were still in the last phases of the previous up cycle. As elsewhere, the pace of contraction accelerated following the failure of Lehman Brothers in September. Recent data on housing starts, retail sales, and the Purchasing Manager's Index project further deceleration in 2009.
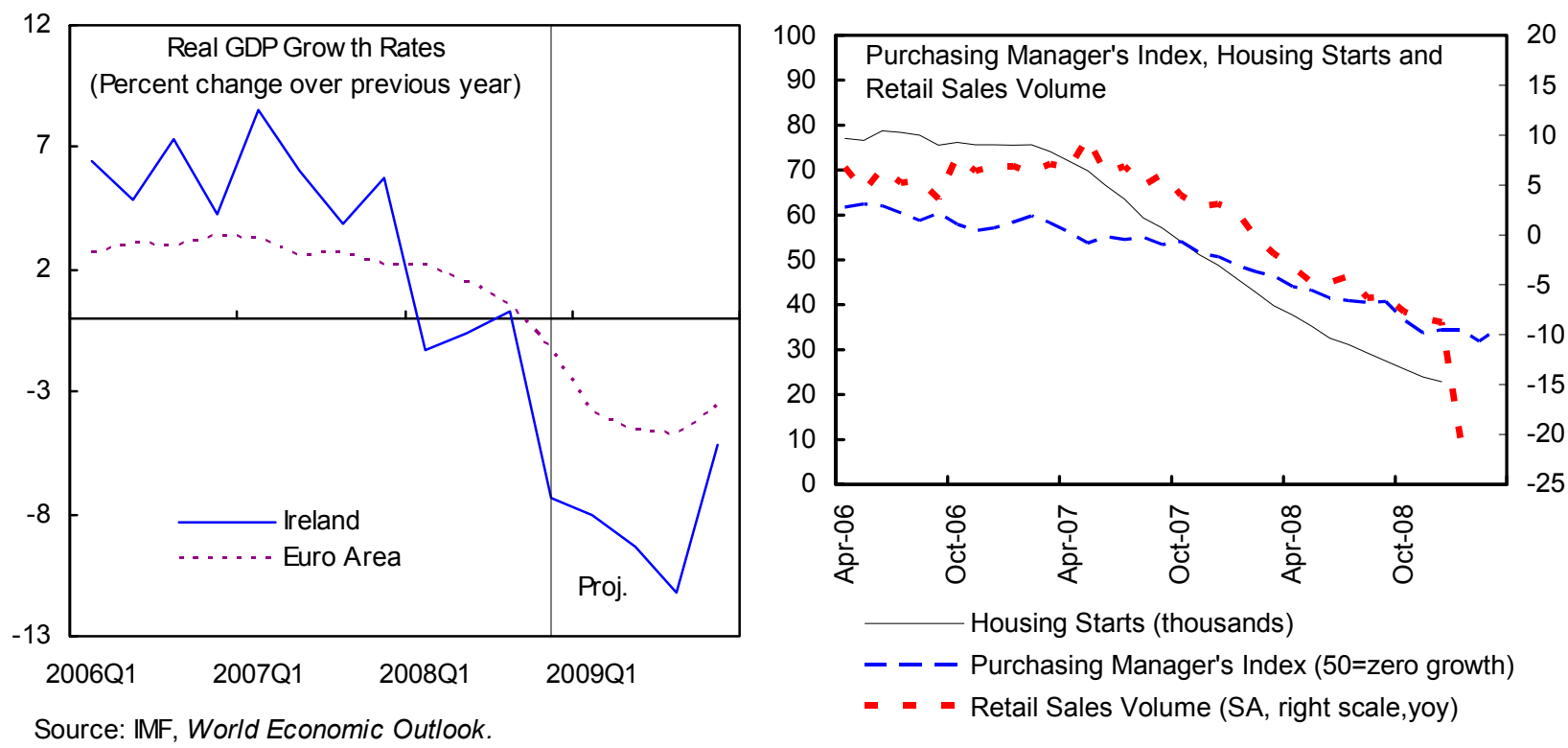

Source: Haver Analytics and Central Statistics Office.

\section{A. The Near-Term Dynamics}

\section{From 2008 through 2010, the Irish economy is projected to contract by about}

$13 \frac{1}{2}$ percent. Following a decline in GDP of $2 \frac{1}{4}$ percent in 2008, staff projects that GDP will shrink by $8 \frac{1}{2}$ percent in 2009 and by a further 3 percent in 2010 (Table 4). The authorities broadly shared this outlook, although the Department of Finance projects a smaller contraction of $73 / 4$ percent in 2009. Private forecasters and the European Commission project a 2009 contraction of 9 percent. All are agreed that the decline is likely to be broad-based. The continuing fall in construction activity will contribute to higher unemployment. The projected decline in exports does not translate into

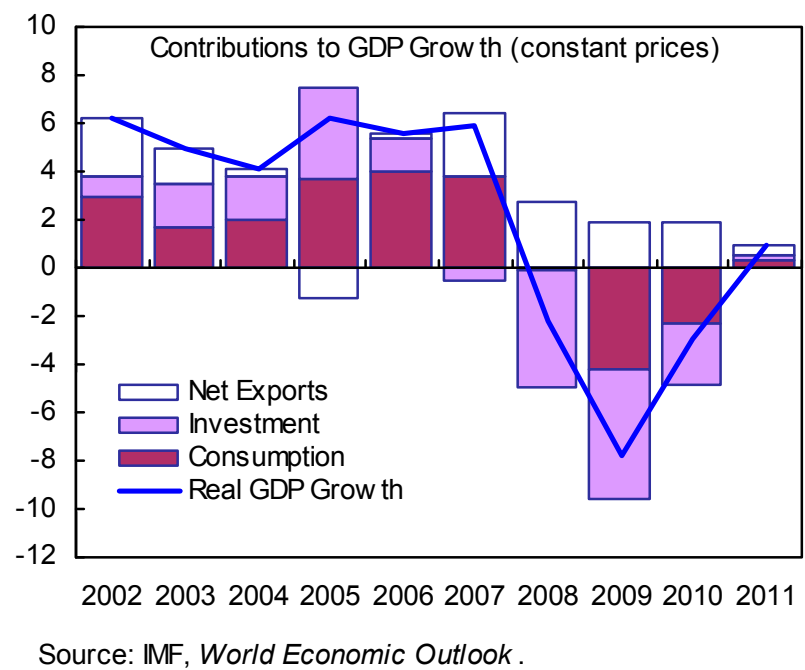


an equal decline in net exports since imports are also falling rapidly. However, the smaller volume of exports will add to unemployment, which is expected to exceed 12 percent by end2009 and reach 151/2 percent in 2010. Some discouraged workers are simply leaving the labor force. These employment trends, along with the anticipated additional decline in nominal wages and the high degree of uncertainty, are expected to pull consumption down sharply.

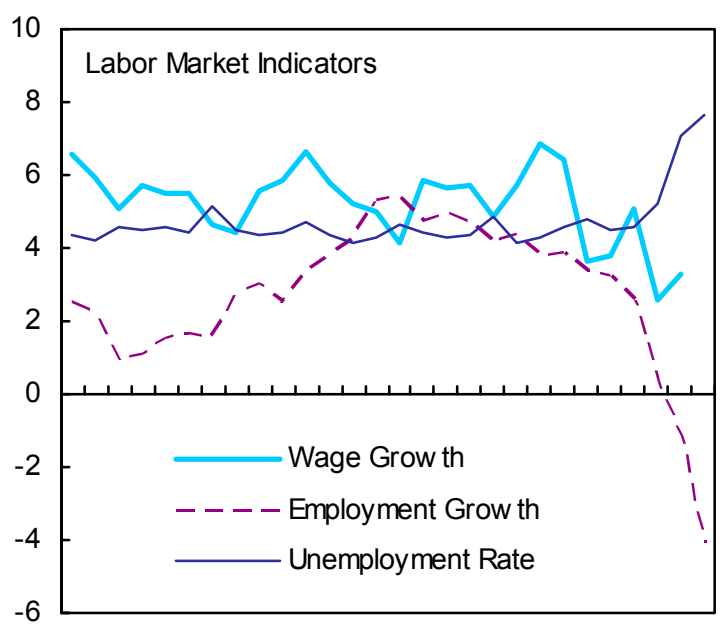

2002Q1 2003Q2 2004Q3 2005Q4 2007Q1 2008Q2

Source: Central Statistics Office.

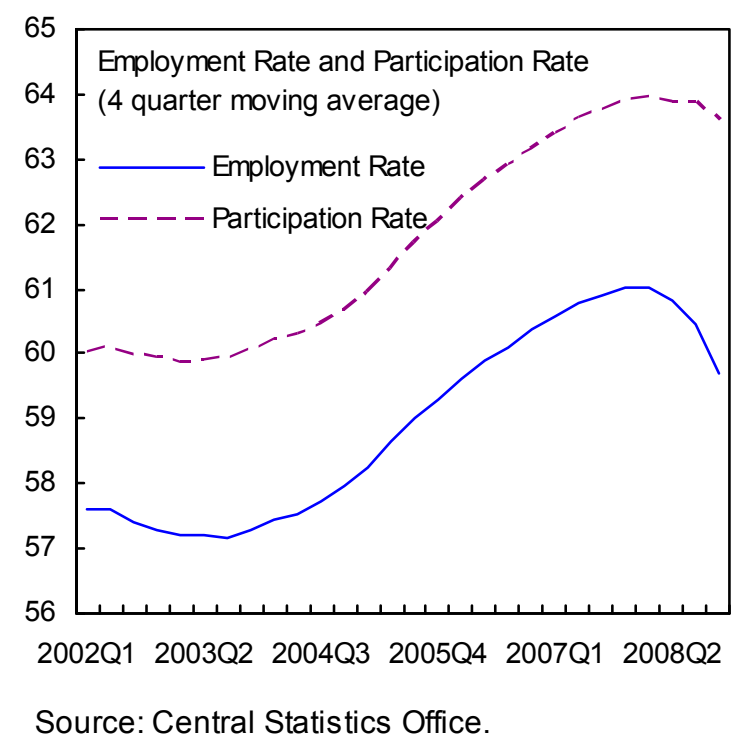

Source: Central Statistics Office.

8. The authorities agree that the risks remain significant. The risks arise from the continuing interaction of slowing growth, financial sector stress, and the state of public finances, with each threatening to pull the other down. If the distress in the financial sector is larger than currently estimated, this damaging reinforcement could accelerate. Ireland also remains susceptible to disruptions from further external shocks.

9. Ireland faces risks from global deleveraging. Continued financial stress in the United States and the United Kingdom could result in large losses for Irish banks that are exposed to the U.S. and the U.K. financial markets. Also, the deleveraging following global losses of international banks could imply sizeable capital outflows from Ireland by foreign banks with subsidiaries or branches re-focusing credit provision in their home markets. Given Ireland's relatively small size in the global context, Irish banks' deleveraging is not likely to generate noteworthy international impulses unless the banks' medium-tern losses were much larger than currently anticipated. 


\section{The bleak short-term outlook and the projection of only a modest pace of} medium-term recovery follow from two considerations. First, Irish output was more than 7 percent above potential in mid-2007 (Box 1). This large gap had emerged due to a burst of activity in the construction and financial intermediation sectors, starting in 2005. Correcting this output gap ("bubble") implies a substantial short-term adjustment. Second, staff analysis shows that after strong growth between 1987 and 2001, which earned Ireland the moniker of the "Celtic Tiger," potential growth had steadily eroded. From a high of 6 percent a year at its peak, potential growth was down to just under 3 percent a year when the crisis hit. Moreover, the correction of distortions induced by the nexus of property and financial developments will further pull down potential growth in the immediate future before it rises back to the 2 percent range by the close of the projection period in 2014. The authorities estimate potential growth at about $2 \frac{1}{2}$ percent, and see more of a bounce-back potential in 2011 and 2012. They agreed, however, that these differences do not alter the policy priorities.

11. Inflation is falling. With the increasing output gap between 2005 and 2007, Irish inflation rose significantly above the eurozone rate. In 2008, the output gap remained positive despite the fall in output, and the HICP-based inflation remained in positive territory. However, the CPI-based measure, which incorporates mortgage interest payments, decelerated more rapidly. In 2009, the authorities and staff project that CPI-based inflation will fall by more than 3 percent. The HICP-based decline in prices is projected to be $1 \frac{1}{2}$ percent in 2009 . In 2010, staff expects the HICP-based inflation to decline further by a $1 / 4$ percent,

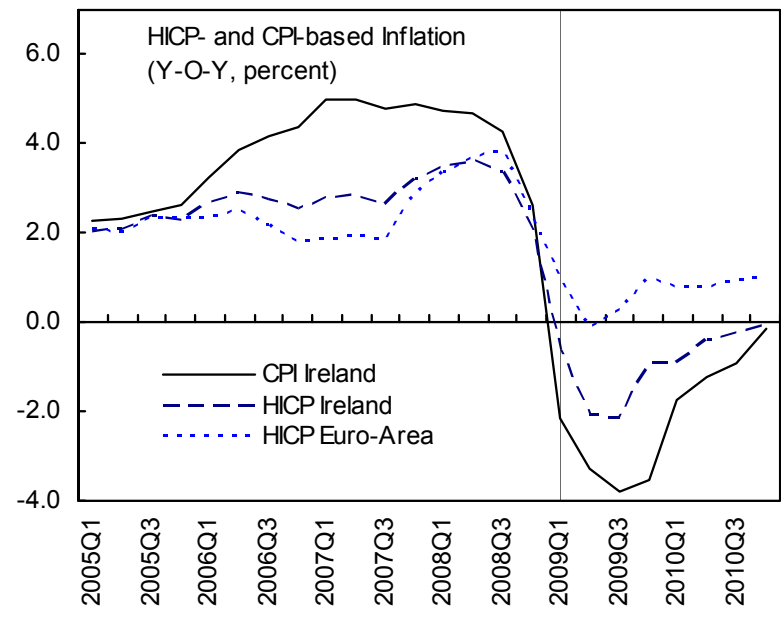

Sources: IMF, World Economic Outlook; and Haver Analytics. while the authorities project a small increase in prices.

12. Falling inflation brings benefits and risks. In the recent past, Ireland's relatively high inflation kept real interest rates low, fuelling the exuberance. Now, Irish prices appear set to decline faster than in the rest of the eurozone. This will help competitiveness, but comes with its own risks. As yet, deflation - or a persistent and large decrease in the price level - is not a threat. However, the projected fall in prices will imply higher real interest rates than in the eurozone, which will dampen the next economic cycle. Given the priority to budget consolidation, a fiscal offset to the dampening will not be feasible, and a credible consolidation would need to lay the basis for a return to healthy expansion. 


\section{Box 1. Decomposing Irish Growth}

Standard techniques, such as the Hodrick-Prescott (HP) filter, tend to miss the phenomenon of "overheating" or "bubbles," treating them as part of the trend rather than unsustainable deviations. Staff analysis has relied, therefore, on a more direct identification of the output gap. Kalman filtering allows the decomposition of trends in GDP into the output gap, which is identified by a set of economicallyplausible correlates, and the underlying potential output growth.

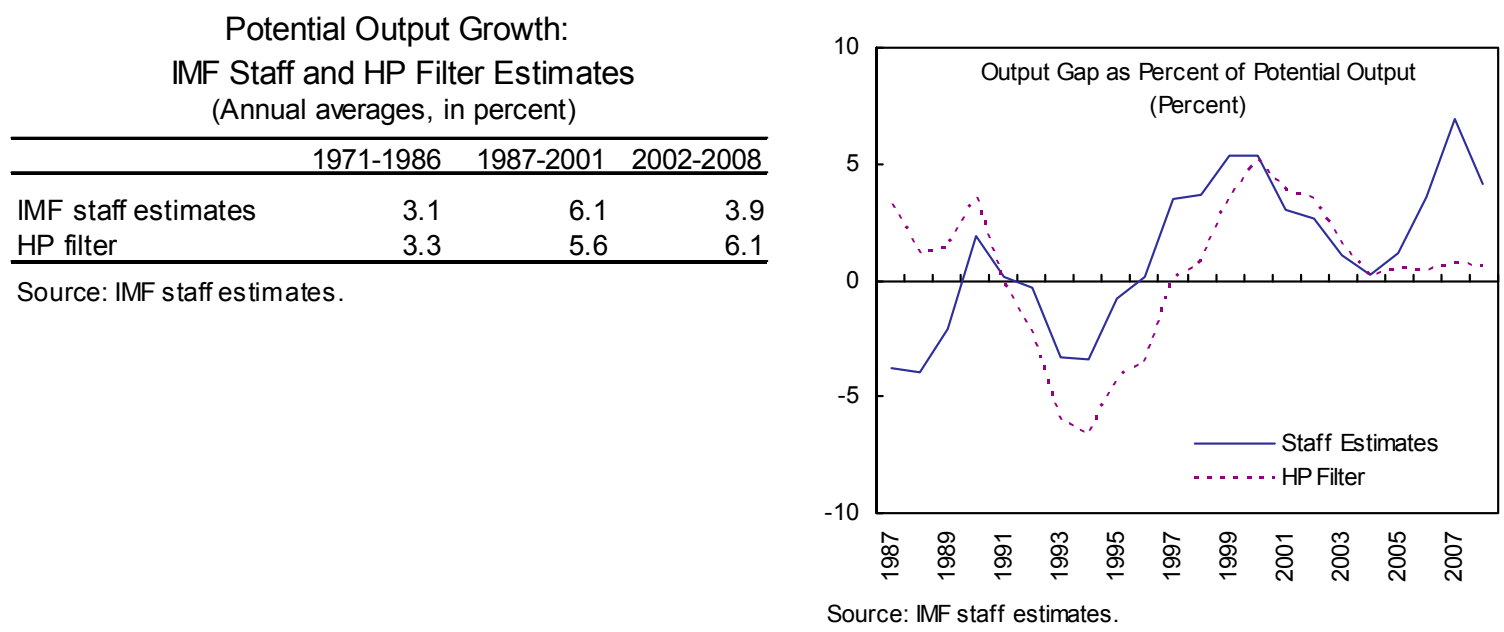

The HP filter concludes that potential growth rate increased steadily from 1971. The high estimate of potential growth leads also to the conclusion that output was at potential in 2007-08, missing the entire overheating phase. As such, in the HP estimates, the loss in potential due, for example, to adverse FDI trends is masked by the rise of the property-finance nexus, which must now substantially contract. In contrast, by staff's estimates, potential GDP growth fell from an annual average rate of 6 percent between 1987 and 2001 to just under 4 percent in the years since then. Within this more recent period, the analysis points to a steady decline, ending in 2008 with the potential growth rate below 3 percent and output significantly above potential.

Analysis by OECD staff, consistent with the results from the Kalman-filtering approach, concludes that Ireland was perhaps the most overheated of all advanced economies. ${ }^{1}$ Since 2005 , the difference between the interest rate implied by the "Taylor's" rule and the actual interest rate was the largest in Ireland. OECD staff also finds that the larger this gap, the more rapid was credit growth, appreciation of property prices, and growth of the construction sector. Thus, within the context of a monetary union, Irish fiscal policy needed to be substantially more aggressive than it was.

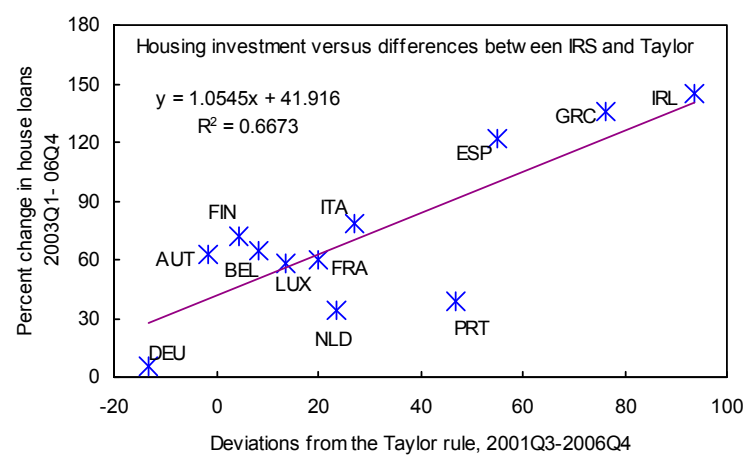

Source: OECD Working Paper No. 597.

${ }^{1}$ Ahrend, Rudiger, Boris Cournède and Robert Price, 2008, "Monetary policy, market excesses and financial turmoil," Economics Department Working Paper No. 597, Organisation for Economic Co-operation and Development, Paris. 


\section{B. Competitiveness}

\section{Irish competitiveness and potential growth have been generally well-matched.}

The 1986-2001 period of the "miracle" was characterized by improving competitiveness and rising potential growth (Figure 2). Wage moderation, given Ireland's highly-open economy, supported the miracle. ${ }^{2}$ Then, as unit labor costs rose, potential output growth steadily declined. Wages rose rapidly despite the traditional flexibility and openness to immigrants. A key factor in this wage rise was generous increases in public wages. In this context, the recent tendency of wages to decline, if sustained, will help regain competitiveness.

14. International market shares have fallen sharply. Following several years of increase, Ireland's international market shares have declined with the rise in unit labor costs and fall in potential growth. This decline is evident since 2002 for all of Ireland's major market destinations. Irish exports of services, particularly business services, have done better than exports of goods. However, they have also begun to level off, and with the likely drop in demand in the short-run, another source of growth will weaken. The private sector and the authorities were also concerned that the recent weakening of the sterling against the euro is

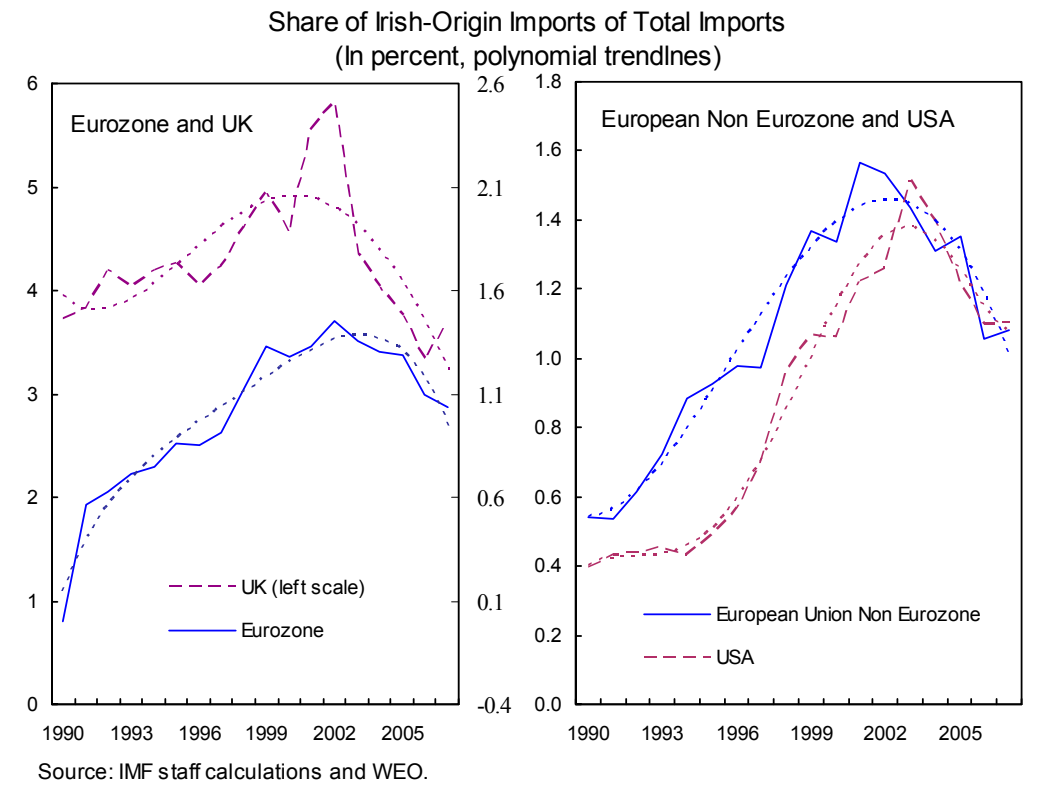
having an adverse impact on Irish exports not just to the U.K. market but also in third markets.

15. Similarly, Ireland has lost market share in the global and eurozone flows of FDI. FDI inflows into the eurozone have tended to fall as a share of world FDI flows (Figure 3). However, Irish FDI shares have fallen faster. In recent years, Ireland has become the most expensive location in the eurozone, with the possible exception of Luxembourg (Figure 4). The transformation from a location for low-cost manufacturing to a center for high valueadded production and services is ongoing. However, research shows that FDI flows to a country are highly influenced by recent momentum — increased global competition for FDI implies that task for Ireland is increasingly harder.

\footnotetext{
${ }^{2}$ Blanchard O., 2002, "Comments on Catching up with the Leaders: the Irish Hare, by Patrick Honohan and Brendan Walsh," Brookings Papers on Economic Activity.
} 
Figure 2. Ireland: Competitiveness and Potential Output Growth

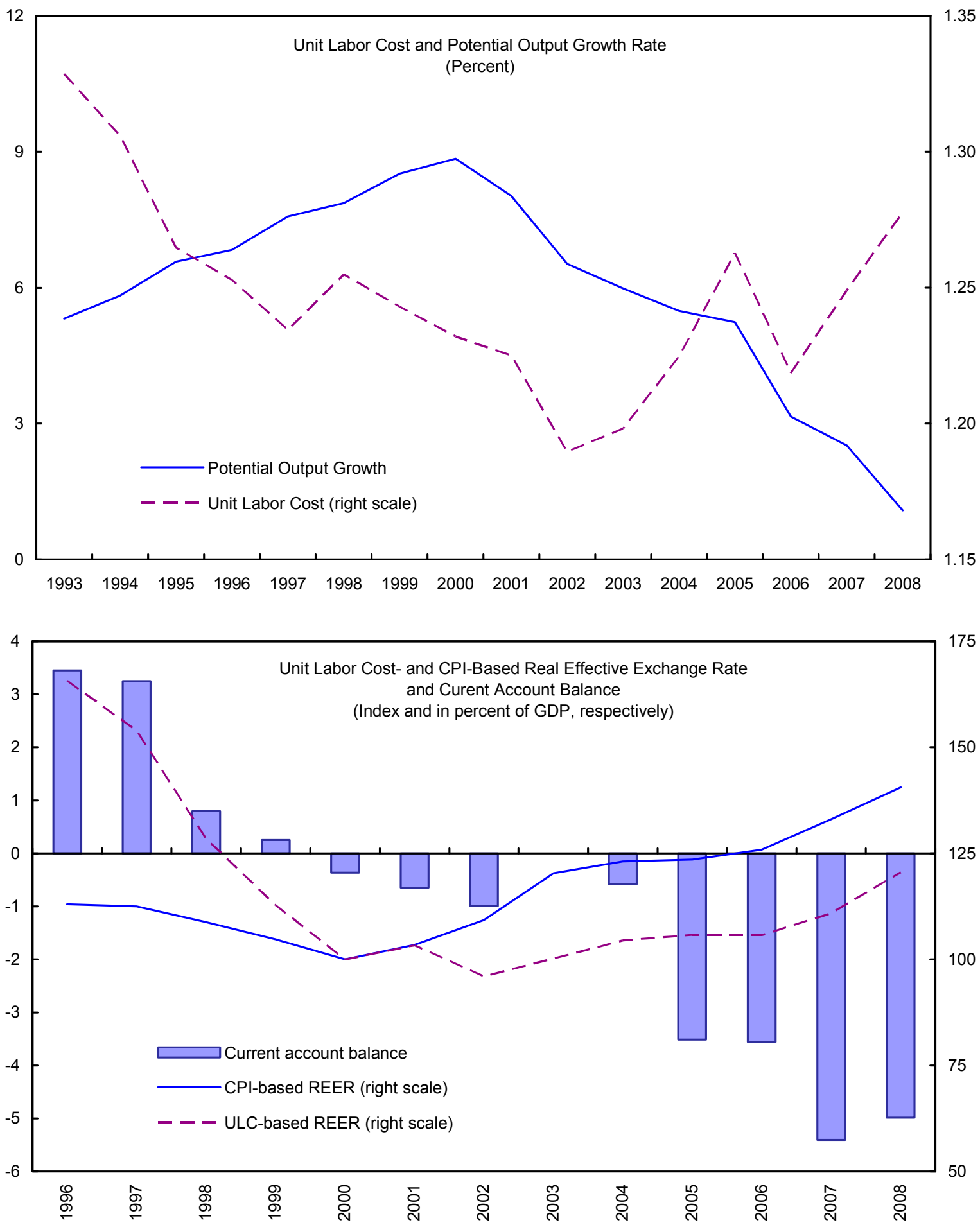

Source: IMF, World Economic Outlook; and IMF staff estimates. 
Figure 3. Shares of Global and Eurozone Foreign Direct Investment (In percent)

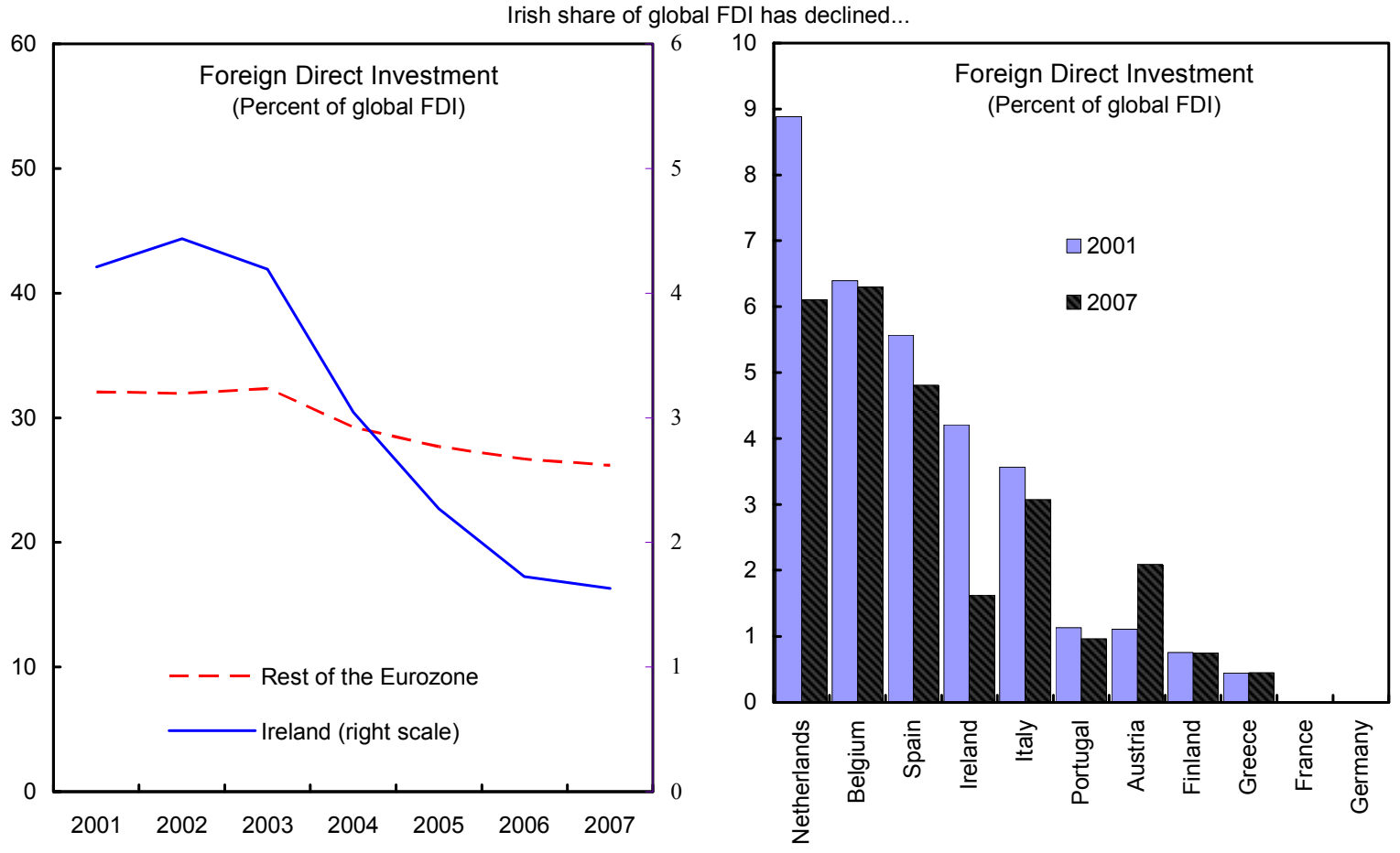

....as has its share in the eurozone.

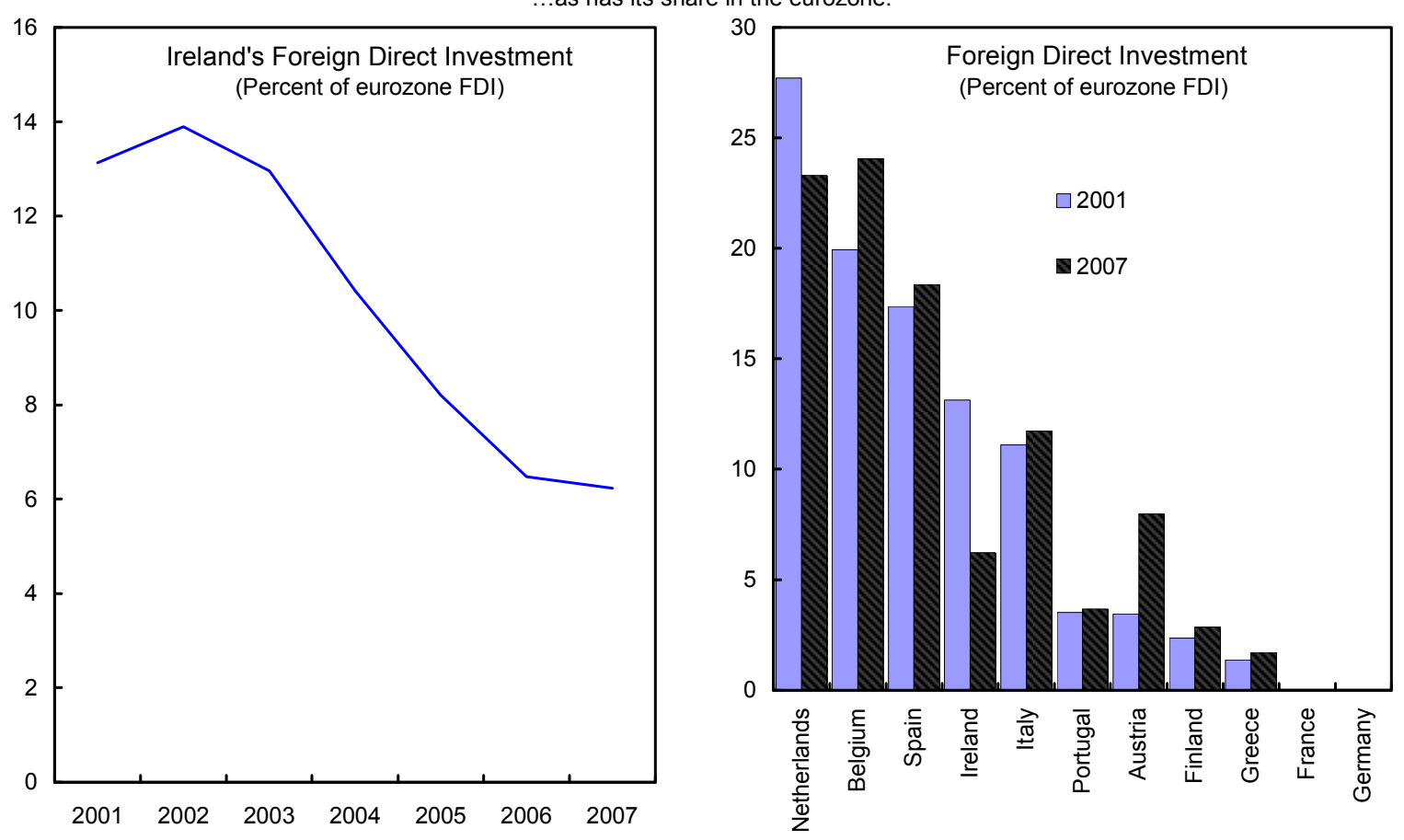

Sources: IMF, World Economic Outlook; and IMF staff estimates. 
Figure 4. Ireland's Labor Cost and Price Levels Relative to the Eurozone
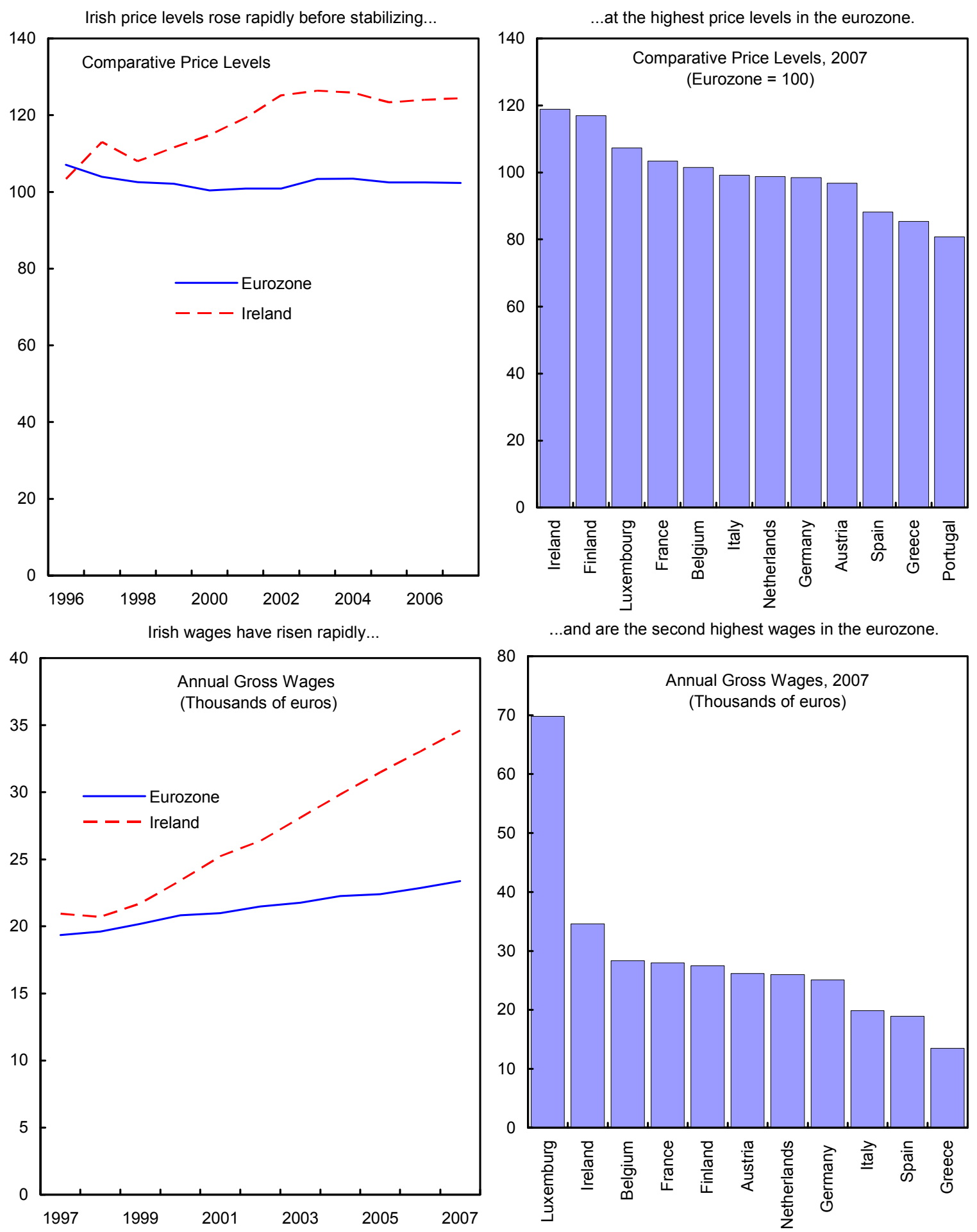

...and are the second highest wages in the eurozone.

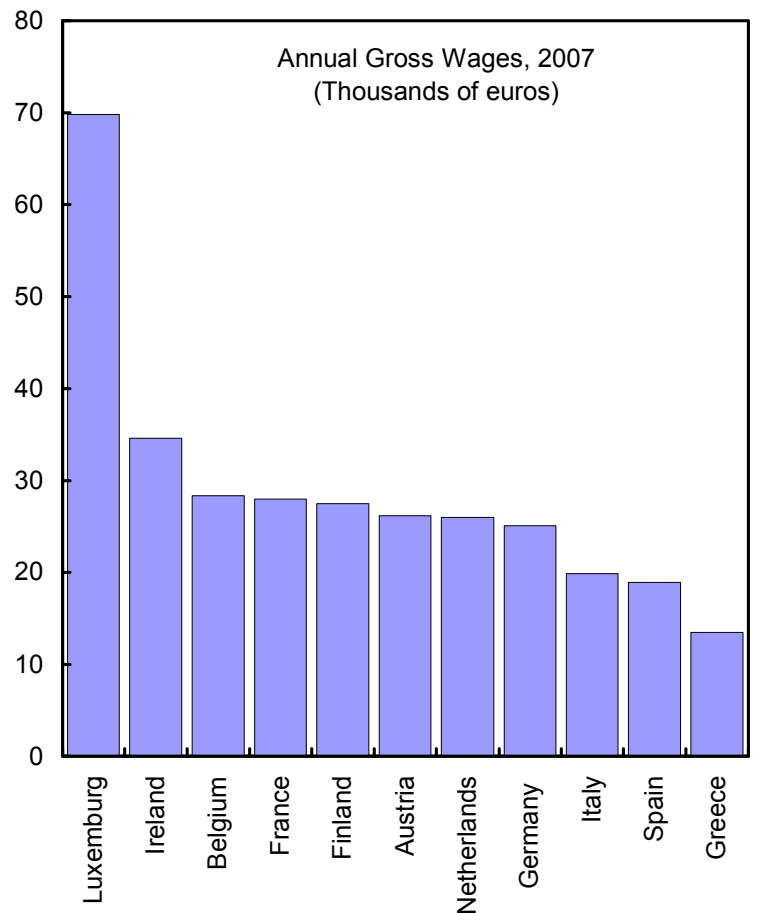

Sources: Eurostat; and IMF staff estimates. 


\section{An application of the CGER methodology shows Ireland faces a significant}

competitive disadvantage. The actual real exchange rate is presently about 20 percent above its long-term average. In contrast, factors such as productivity gain have only modestly raised the equilibrium exchange rate, which is about 5 percent above its long-term average, leaving a 15 percent gap. Entry into the eurozone at a favorable exchange rate allowed some years of competitive strength.

However, that

advantage has given way to a sizeable gap, reflected also in the high Irish prices and wages levels (Figure 4) and loss of Ireland: Applications of the CGER Methodology

\begin{tabular}{lccc}
\hline & Macro-Balances & $\begin{array}{c}\text { External } \\
\text { Sustainability }\end{array}$ & $\begin{array}{c}\text { Equilibrium Real } \\
\text { Exchange Rate }\end{array}$ \\
\hline Current account norm & -0.8 & -0.9 & $\ldots$ \\
Underlying current account balance 1/ & -4.3 & -4.3 & $\ldots$ \\
Competitiveness gap 2/ & 8.8 & 6.7 & 15.3 \\
\hline
\end{tabular}

Source: IMF staff calculations; and CSO.

1/ Current account balance for 2014 adjusted for projected change in real effective exchange rate over the medium term. 2/ Adjusted for multilateral consistency.

market shares. The

other two CGER-type measures show somewhat smaller gaps. These depend sensitively on estimates of the "underlying" current account balance, calculated to be about $4 \frac{1}{2}$ percent of GDP (as it was in 2008) and the elasticity of adjustment to the real effective exchange rate.

\section{While the authorities concurred that there had been a significant loss in} competitiveness, they had a more optimistic prognosis. In particular, they viewed recent nominal wage cuts as a reflection of Irish labor market flexibility, creating the potential to recover competitiveness. The authorities also pointed to the relative resilience of Irish chemical and pharmaceutical exports in recent quarters. Staff pointed out that adjustments to various degrees were also occurring in other countries but agreed that, if sustained, the recent wage and price trends would improve Irish competitiveness. As such, the current account deficit in 2014 is projected at 1 1/2 percent of GDP, significantly lower than the present "underlying" deficit, though higher than near balance expected in the short term because of severe demand compression. Staff recommended that competition policy and the mandate of the Competition Authority be used to support the process of price and wage adjustment. ${ }^{3}$

\section{Managing Financial Sector Stress}

\section{Domestic vulnerabilities have interacted rapidly with the global financial crisis.} Domestic vulnerabilities are revealed in the sharp decline in the stock prices of Irish banks relative to the overall stock index, the pronounced degree of this fall differentiating Ireland from other eurozone banks (Figure 1). Three key features of the financial system have been central to the strains they are facing.

\footnotetext{
${ }^{3}$ The OECD concludes that more is needed, for example, to boost competition in network industries and sheltered service sectors (OECD Economic Surveys: Ireland, volume 2008/5).
} 
- The domestic loan portfolio is heavily concentrated in residential mortgages, construction, real estate development, and commercial property (Table 5). The sharpcorrection in property prices lies at the heart of the losses that banks face.

Residential mortgage servicing has held up, but arrears have been growing and will likely increase as the unemployment rate rises. Some Irish banks are also exposed to risks from their substantial property and home mortgage lending in the U.K.

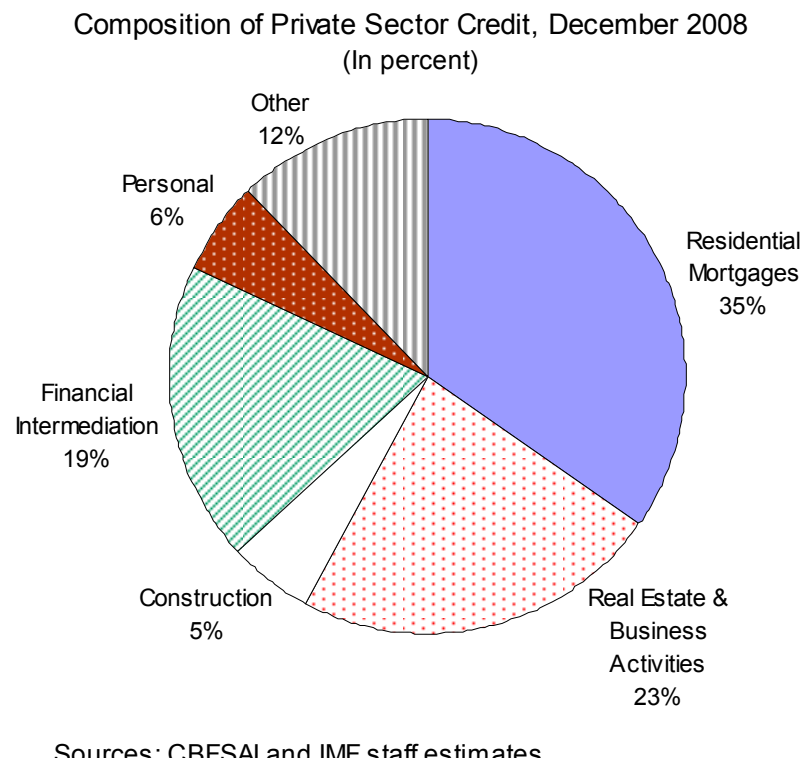

- $\quad$ Irish interest margins were low

Sources: CBFSAl and IMF staff estimates. by international standards. As the crisis has unfolded, margins have been under further pressure with the sharp decline in lending rates (especially for mortgages, which are predominantly on variable rate terms).
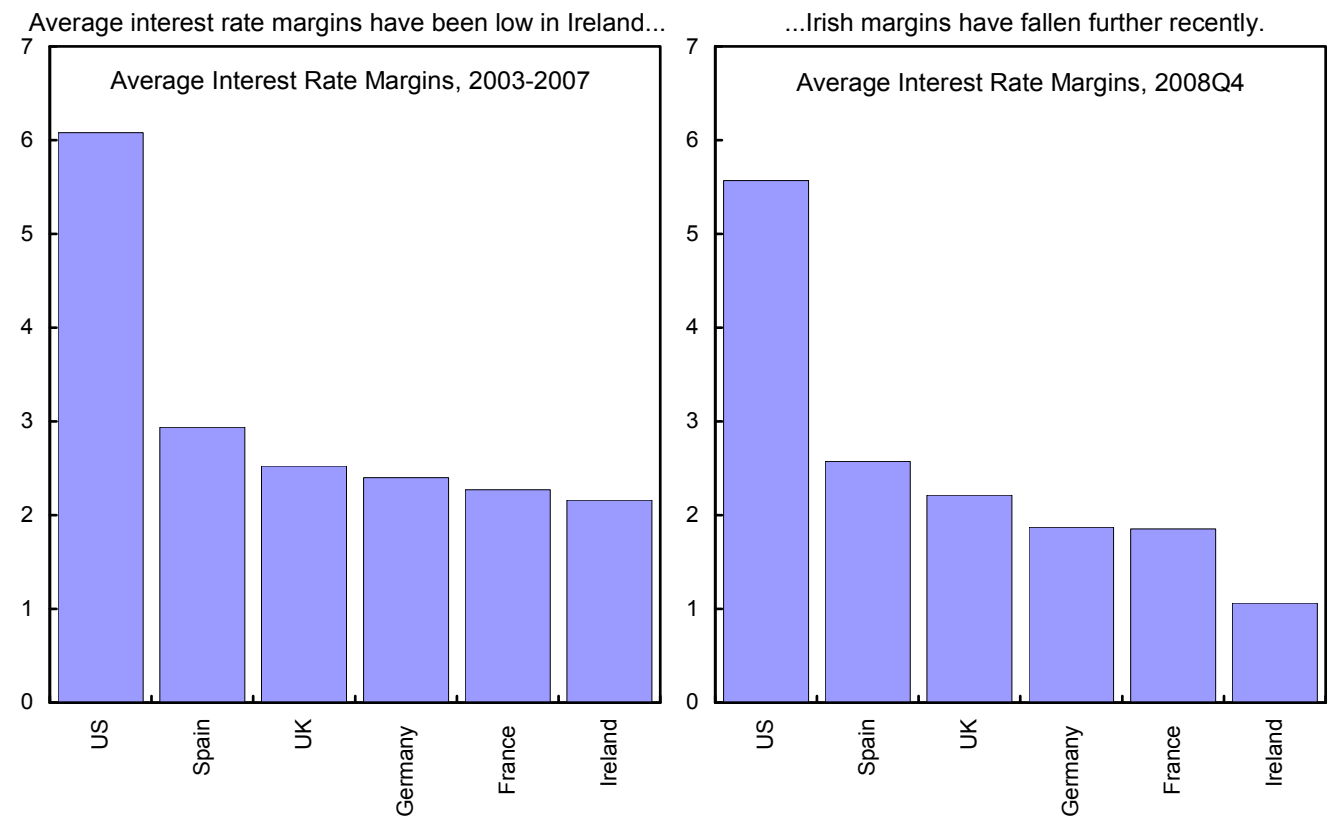

Sources: Haver Analytics; and IMF staff estimates. 
- In the past, profitability was maintained through large lending volumes. But since domestic deposit growth did not keep up with the lending targets, reliance on wholesale funding increased, reflected in the rise of the loan-to-deposit ratio. With the recent downturn, market funding pressures have been compounded by lack of growth in deposits.

- The government's guarantee to depositors and creditors and the capital injections have helped banks obtain market funding, and access to ECB facilities has been an important stabilizing factor.

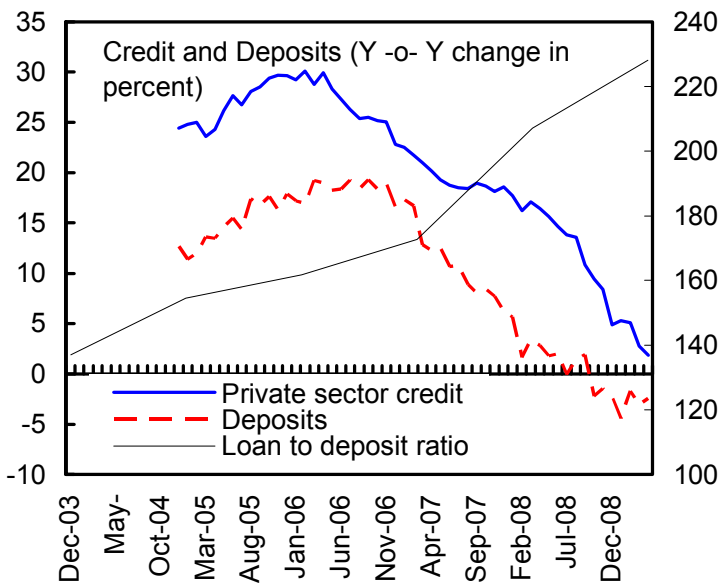

Source: Central Bank of Ireland.

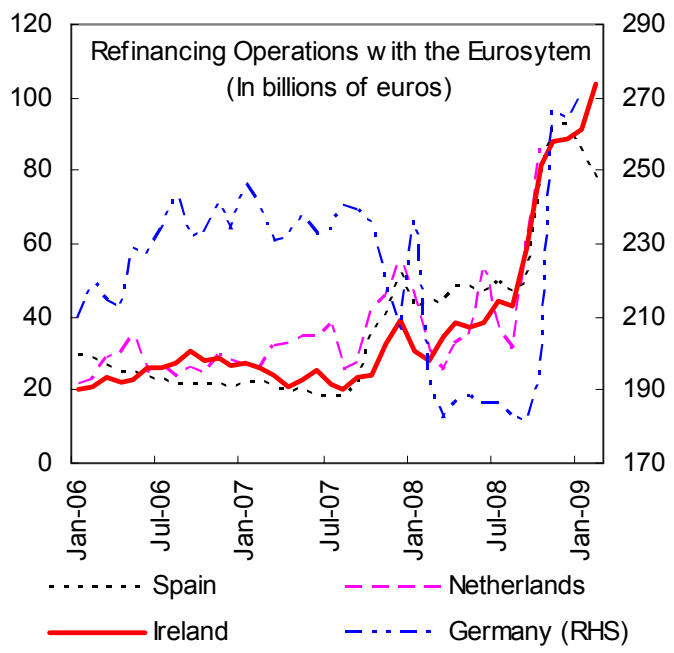

Sources: Central Banks of Spain, Ireland, Netherlands, and Germany.

Domestic banks have expanded their use of ECB facilities in recent months.

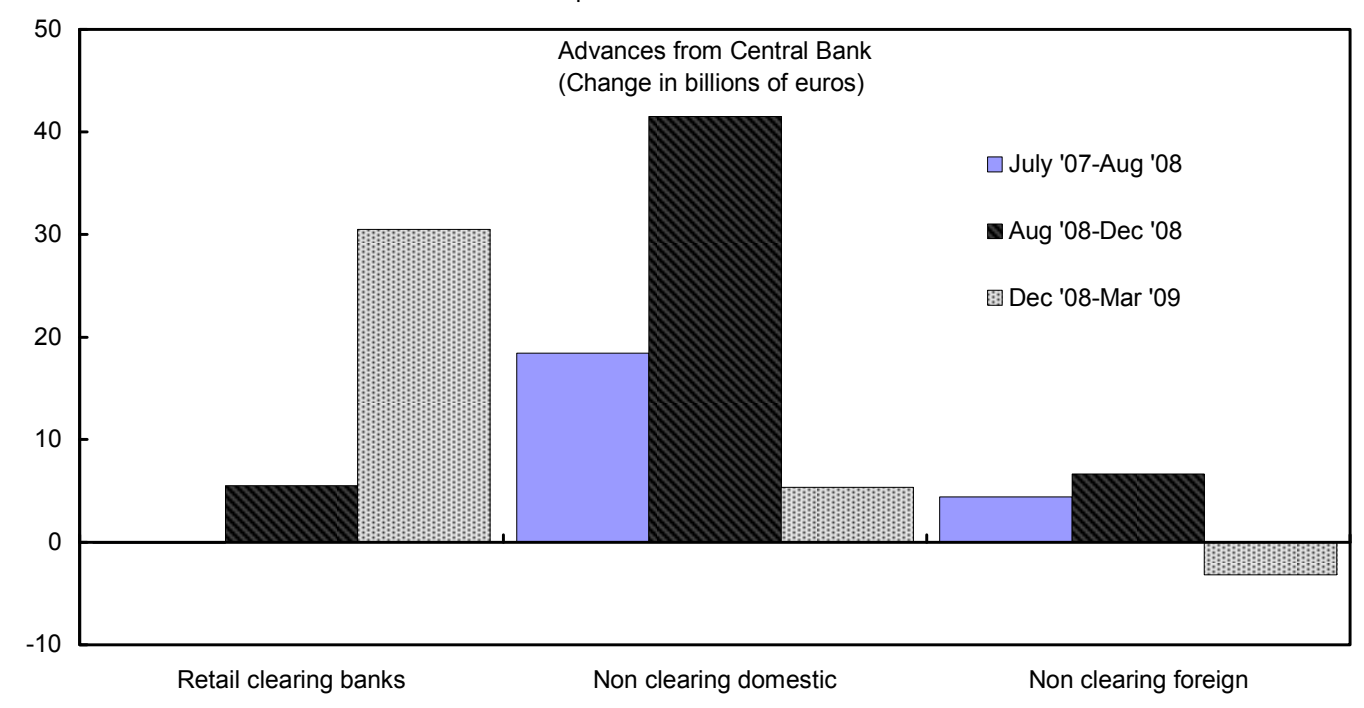

Source: Central Bank of Ireland. 


\section{The authorities' extensive and ongoing support has been vital to maintain financial stability.}

- $\quad$ On September 30, 2008, following the failure of Lehman Brothers, the government provided a blanket guarantee to the depositors and creditors of six domestic banks. ${ }^{4}$ The guarantee, covering over 200 percent of Irish GDP, is much larger than in other countries.

- $\quad$ Anglo Irish Bank was nationalized in January 2009. And, on February 11, 2009, the authorities announced the injection of $€ 7.0$ billion into the two largest banks-Bank of Ireland and Allied Irish Bank-totaling 4 percent of GDP. The scale of the capital injections is, thus far, in line with similar efforts elsewhere.

- Finally, the authorities' decision, announced in the April supplementary budget, to establish the National Asset Management Agency (NAMA), marks a significant step in beginning the process of bank restructuring.

\section{A. Bank Restructuring}

20. Estimates of losses being faced by banks vary but are likely to be sizeable. On a gross basis, staff's review of available estimates and methodologies suggests that the losses faced by banks through the end of 2010 could be about $€ 35$ billion, or about 20 percent of GDP. The authorities did not formally produce any estimate for aggregate bank losses. They have focused on the needed restructuring of property-development loans, which they rightly view as at the heart of stress faced by banks. Staff noted that losses are likely to extend beyond the property-development sector as the economy weakens and the design of NAMA should incorporate that possibility.

21. As the authorities recognize, translating NAMA from concept to reality is pivotal to the orderly restructuring of the financial sector and limiting long-term damage to the economy. NAMA is to purchase property-development assets with a book value of between $€ 80$ and $€ 90$ billion from banks that are supported by the government's guarantee. (The total assets of the guaranteed banks are $€ 440$ billion.) Since the assets are to be purchased at less than their book value, the resulting losses will require the authorities to inject more capital into some banks. If well managed, the distressed assets acquired by NAMA could, over time, produce a recovery value to compensate for the initial fiscal outlays. NAMA's success will also be the precondition for a safe exit from the guarantee to creditors and depositors, which recent experience shows can be a long-drawn process unless

\footnotetext{
${ }^{4}$ The guarantee covered all retail and corporate deposits, interbank deposits, covered bonds (including asset covered securities), senior unsecured debt and dated subordinated debt.
} 
aggressively managed (Text Table 1). If not effectively managed, weakness of the financial sector, public finances and economic growth can reinforce each other (Box 2).

Text Table 1. Exiting From Blanket Guarantees: Selected Country Experiences

\begin{tabular}{|c|c|c|c|}
\hline Country & Blanket Guarantee & Coverage & Elimination strategy \\
\hline $\begin{array}{l}\text { Finland } \\
\text { 1993-98 }\end{array}$ & $\begin{array}{l}\text { The government announced in } \\
\text { August } 1992 \text { that the stability of the } \\
\text { Finnish banking system would be } \\
\text { secured. Guarantee was formalized } \\
\text { by parliament in January } 1993 \text {, } \\
\text { replacing the previous partial deposit } \\
\text { guarantee. }\end{array}$ & $\begin{array}{l}\text { All bank liabilities (deposits, } \\
\text { contingent and foreign } \\
\text { currency liabilities); equity } \\
\text { holders were excluded. }\end{array}$ & $\begin{array}{l}\text { Removed in December } \\
1998 .\end{array}$ \\
\hline $\begin{array}{l}\text { Indonesia } \\
\text { 1997-2007 }\end{array}$ & $\begin{array}{l}\text { Approved in January } 1998 \text {, replacing } \\
\text { a partial insurance scheme } \\
\text { introduced in October } 1997 .\end{array}$ & $\begin{array}{l}\text { All deposits and other credits } \\
\text { of all domestic banks } \\
\text { (excluding shareholders' } \\
\text { capital, subordinated debt, } \\
\text { and insider deposits). }\end{array}$ & $\begin{array}{l}\text { Initially set to last at least } \\
\text { two years, phased out } \\
\text { between July } 2005 \text { and } \\
\text { March } 2007\end{array}$ \\
\hline $\begin{array}{l}\text { Japan } \\
\text { 1998-2005 }\end{array}$ & $\begin{array}{l}\text { Announced by the Ministry of } \\
\text { Finance in November } 1997 \text { and } \\
\text { passed into law in February 1998, } \\
\text { replacing the limited insurance } \\
\text { scheme. }\end{array}$ & $\begin{array}{l}\text { Deposits and other credits of } \\
\text { commercial banks, credit } \\
\text { cooperatives, labor and credit } \\
\text { associations. }\end{array}$ & $\begin{array}{l}\text { Lifted for time deposits in } \\
\text { April } 2002 \text { and for } \\
\text { demand deposits in April } \\
2005 .\end{array}$ \\
\hline $\begin{array}{l}\text { Korea } \\
\text { 1997-2000 }\end{array}$ & $\begin{array}{l}\text { Introduced in August } 1997 \text { for banks' } \\
\text { external liabilities and extended in } \\
\text { November } 1997 .\end{array}$ & $\begin{array}{l}\text { All liabilities (excluding } \\
\text { shareholders' capital and } \\
\text { subordinated debt) of banks, } \\
\text { securities companies, } \\
\text { insurance companies, } \\
\text { merchant banks, mutual } \\
\text { savings and finance } \\
\text { companies, and credit } \\
\text { unions. Overseas branches } \\
\text { were also included. }\end{array}$ & $\begin{array}{l}\text { Lifted at end- } 2000 \text { as } \\
\text { initially planned. }\end{array}$ \\
\hline $\begin{array}{l}\text { Sweden } \\
\text { 1992-96 }\end{array}$ & $\begin{array}{l}\text { Announced in September } 1992 \text { and } \\
\text { approved by parliament in } \\
\text { December. There was no existing } \\
\text { formal deposit insurance scheme. }\end{array}$ & $\begin{array}{l}\text { Deposits, contingent and } \\
\text { foreign liabilities (excluding } \\
\text { equity) of banks, their } \\
\text { subsidiaries and some } \\
\text { specialized financial } \\
\text { institutions. }\end{array}$ & Removed in July 1996. \\
\hline $\begin{array}{l}\text { Turkey } \\
\text { 1997-2004 }\end{array}$ & $\begin{array}{l}\text { An unofficial guarantee had been in } \\
\text { place from } 1997 . \text { It was officially } \\
\text { confirmed in December } 2000 \text { and } \\
\text { became effective in January } 2001 .\end{array}$ & $\begin{array}{l}\text { Deposits, contingent and } \\
\text { foreign liabilities (excluding } \\
\text { equity) of private and state } \\
\text { banks. Excluded were } \\
\text { offshore deposits and } \\
\text { deposits by owners, deposits } \\
\text { in connection with criminal } \\
\text { activities, subordinated debt, } \\
\text { and shareholder equity. }\end{array}$ & $\begin{array}{l}\text { Abolished in July } 2004 \\
\text { and replaced with a } \\
\text { limited deposit insurance } \\
\text { scheme, protecting } \\
\text { savings deposits up to } \\
\text { TL } 50 \text { billion }(\$ 37,000) \text {. }\end{array}$ \\
\hline
\end{tabular}




\section{A key aspect of NAMA's success will be the prices at which the assets are}

purchased. This will determine the extent to which banks' losses are transferred to the taxpayer. Since price determination is a major challenge, risk-sharing structures could be usefully explored. For example, if sold at a price that is clearly lower than the expected eventual recovery value, bank shareholders could be given a share in the upside. Similarly, the government could be given an opportunity to participate in the upside of the residual healthy bank. The authorities noted that they remained open to a number of refinements, including such upfront risk-sharing structures. Also, while there has been some public discussion of a bank-specific ex post "claw back" provision, the authorities are considering an industry-wide levy to recoup any losses suffered by NAMA.

\section{Box 2. Financial Vulnerability, Public Finances, and Economic Growth}

Following the rescue of Bear Stearns in March, 2008, staff analysis shows that a relationship emerged between financial sector vulnerability and the state of public finances. As financial stocks fell in relation to the overall stock market, the sovereign bond spreads (over the German Bund) increased. This was so for virtually all countries in the eurozone - but the relationship was particularly acute in Ireland. The relationship intensified following the nationalization of Anglo Irish in the second week of January 2009 when financial stocks took another pounding while the spread on the Irish sovereign bonds spiraled to about 250 basis points. In recent weeks, Irish sovereign spreads have moderated with easing global sentiment. However, they remain at elevated levels, and the analysis shows that financial sector, public finances, and economic growth weaknesses could continue to reinforce each other.

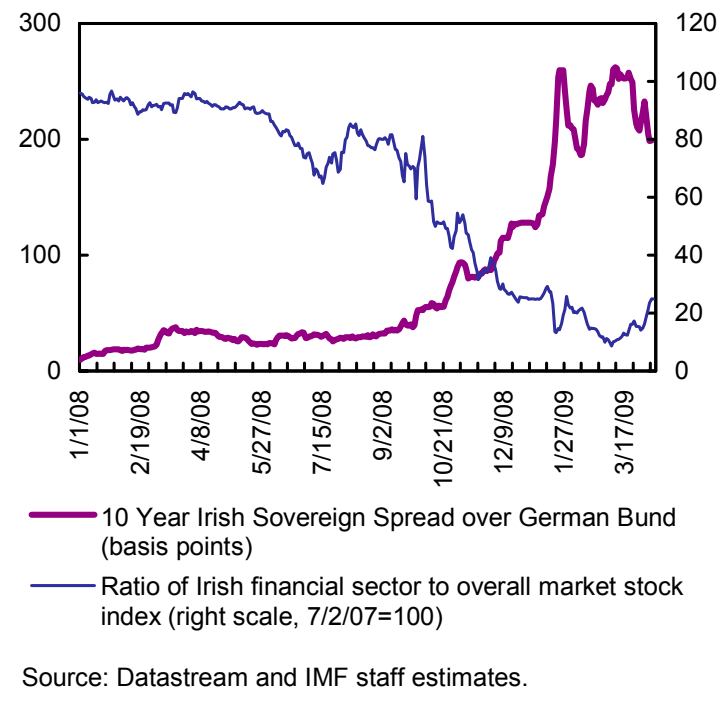

23. With the economic uncertainties that lie ahead, staff emphasized two strategic implications for the design and operation of NAMA. If the banks are not fully relieved of their impaired assets - are not "cleaned up"- their return to normal functioning will be delayed. As such, a full scoping out of the likely distress is needed and a flexible legislative authorization and operational approach should permit NAMA to deal with further deterioration in bank balance sheets. For these reasons, staff advised that the authorities not restrict the focus of NAMA on property-development loans. Other asset classes could deteriorate as the economy continues to contract and unemployment rises. The sharp ongoing rise in troubled loans is a warning that this possibility needs to be seriously considered. 


\section{The authorities took note of these considerations for their further deliberations}

on setting up NAMA. They agreed that piecemeal efforts could keep banks dependent on official support and unable to resume normal functioning. The Japanese experience is particularly cautionary. The authorities saw merit in staff's suggestion that NAMAimplementing legislation should encompass a broader range of loan types. ${ }^{5}$

\section{Staff noted that nationalization could become necessary but should be seen as} complementary to NAMA. Where the size of its impaired assets renders a bank critically undercapitalized or insolvent, the only real option may be temporary nationalization. Recent Fund advice in this regard is: "Insolvent institutions (with insufficient cash flows) should be closed, merged, or temporarily placed in public ownership until private sector solutions can be developed ... there have been numerous instances (for example, Japan, Sweden and the United States), where a period of public ownership has been used to cleanse balance sheets and pave the way to sales back to the private sector." ${ }^{6}$ Having taken control of the bank, the shareholders would be fully diluted in the interest of protecting the taxpayer and thus preserving the political legitimacy of the initiative. The bad assets would still be carved out, but the thorny issue of purchase price would be less important, and the period of price discovery longer, since the transactions are between two government-owned entities. The management of the full range of bad assets would proceed under the NAMA structure. Nationalization could also be used to effect needed mergers in the absence of more far reaching resolution techniques.

\section{The authorities prefer that banks stay partly in private ownership to provide} continued market pricing of their underlying assets. They disagreed with the staff's view that pricing of bad assets would be any easier under nationalization. They were also concerned that nationalization may generate negative sentiment with implications for the operational integrity of the banks. Staff emphasized nationalization would need to be accompanied by a clear commitment to operate the banks in a transparent manner on a commercial basis. In particular, nationalized banks should be subject to the same capital requirements and supervisory oversight as non-nationalized banks. And, a clear exit strategy to return the banks to private operation would be needed.

\footnotetext{
${ }^{5}$ To staff's query regarding the acquisition by NAMA of "good" property-development assets, the authorities responded that markets needed to be reassured that this asset class was fully dealt with.

${ }^{6}$ Group of Twenty Meeting of the Ministers and Central Bank Governors, March 13-14, 2009, London, U.K., Global Economic Policies and Prospects, Note by the Staff of the International Monetary Fund.
} 


\section{B. Supporting Measures}

27. Accompanying these immediate crisis management tasks are several supportive crisis prevention measures. These fall into two broad categories: (a) a framework for bank resolution; and (b) enhancements to supervision. Guided by evolving global and European Union norms, the authorities are engaged in tailoring these to domestic circumstances.

\section{A broader tool kit should allow for more speedy and less disruptive resolution of} banks. When faced with an insolvent bank, Irish authorities can place the bank in a courtsupervised insolvency proceeding. To avoid the disruption that this entails for the customers of the bank and to preserve confidence in the system, special legislation was passed allowing the authorities to nationalize Anglo Irish Bank. ${ }^{7}$ The authorities were open to exploring the merits of a special bank resolution regime. Such a regime would recognize the unique role played by banks in the economy and give the authorities the power to quickly transfer assets and deposits to another institution (a purchase-and-assumption transaction) or to establish a bridge bank (a new limited life bank into which the old bank is transferred to facilitate its sale). The experience with Northern Rock prompted the U.K. to adopt a special resolution regime to add flexibility in dealing with insolvent banks. The enhanced deposit protection under the European Union guidelines would also strengthen the safety net.

\section{The authorities are undertaking several supervisory and regulatory initiatives.}

First, they reported substantial additions of staff enabling them to intensify bank-by-bank surveillance for systemic risks. In this regard, they noted that since January 1, 2003, the concept of a distinct International Financial Services Center no longer exists. Second, they had already moved in establishing a macro-prudential supervisory process that blends considerations of systemic stability with managing the stress in individual financial institutions, in line with the de Larosière report. ${ }^{8}$ The authorities agreed that success of this initiative would require further investment in the development of early warning systems and identification of systemic risks, along with necessary precautionary actions. Finally, further safeguards are needed to limit the risks of related-party lending by banks. The authorities are implementing a requirement for the disclosure of related-party exposures. Safeguards should lower the applicable limits, specify non-favorable terms for the transactions, and require strict approval procedures.

\footnotetext{
${ }^{7}$ If needed, the government will compensate the shareholders following a valuation assessment.

8 “The High-Level Group on Financial Supervision in the EU,” Jacques de Larosière, Chairman, February 2009.
} 


\section{Achieving Fiscal Credibility}

\section{Well before the crisis hit, public finances had developed serious structural}

weaknesses. The facts are well known. In the boom years, personal income tax rates were lowered and expenditure grew rapidly (at about the highest pace among OECD economies). Buoyant property-related revenues (stamp duties, VAT, and capital-related taxes) masked the growing structural deficit, which reached 121/2 percent of GDP in 2008 (Box 3). To the authorities' credit, some revenues were set aside in the National Pensions Reserve Fund (NPRF). The NPRF is being used for bank recapitalization needs. This, however, has diluted its primary role as a cushion for long-term obligations related to the aging population, to which it would need to return.

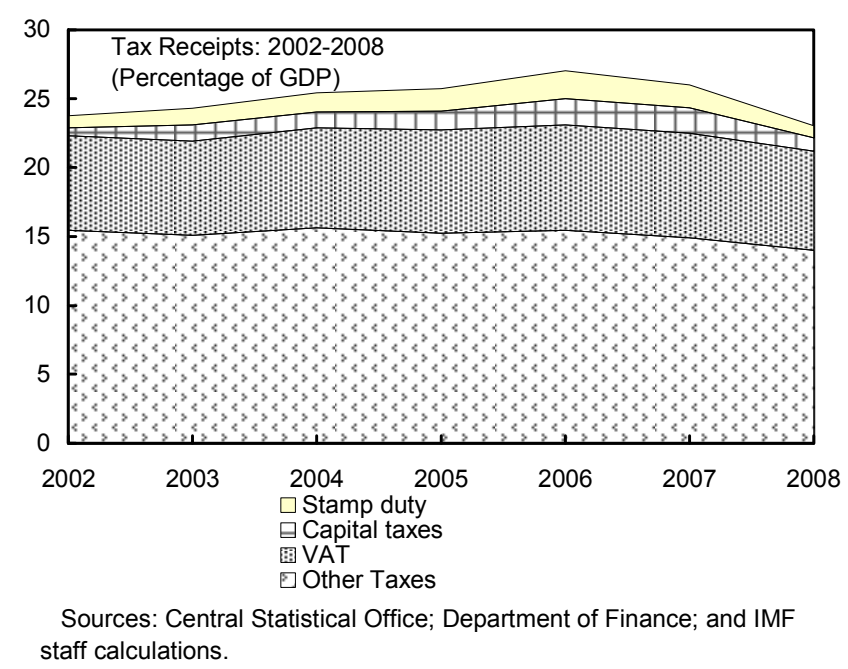
staff calculations.

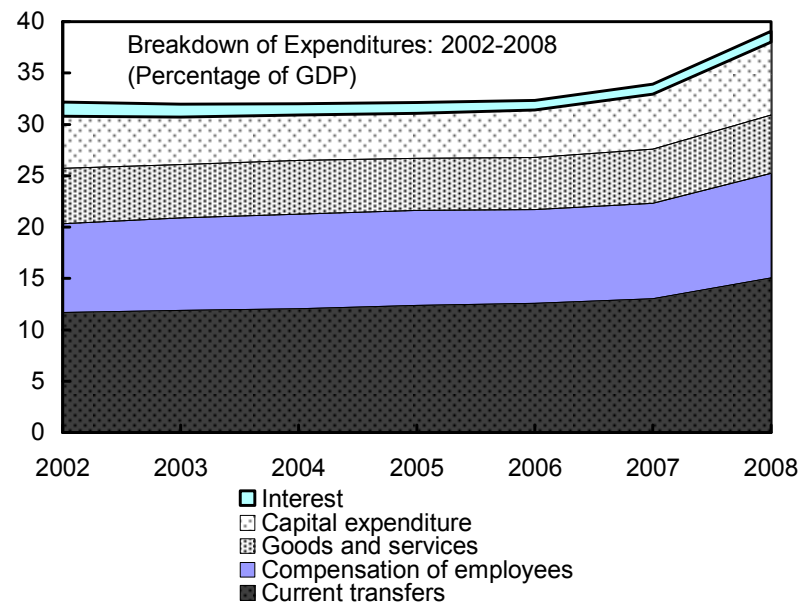

Sources: Central Statistical Office; Department of Finance; and IMF staff calculations.

\section{Regaining credible control over public finances will require a steady hand over}

several years. With the large looming deficits, the task of consolidation presents formidable challenges. The needed consolidation comes at a moment when the economy is undergoing substantial contraction and prices are likely to fall for a number of quarters. The consolidation will help the recovery only if it generates confidence that a fundamentallystrong reorientation of government priorities is under way. If not done right, the downturn could worsen. This, in turn, will require a substantial effort to scale back the scope of government activities and to improve the efficiency of government services. The tax base must be broadened, while limiting the impact on unit labor costs. 


\section{Box 3. Ireland's Structural Deficit}

In the economic upswing, asset-based taxes came to be regarded as a stable source of revenues. However, these have proven to be largely temporary. In 2007, when the headline budget was in balance, the staff's estimate is that adjusting for the large positive output gap and the effect of the asset price bubble, the structural deficit was about 83/4 percent of GDP. An expansionary budget in 2008 widened the structural deficit to 121/2 percent of GDP. Following the April 2009 supplementary budget, the structural deficit remains at about 11 percent of GDP in 2009. It is from this base that the challenges ahead must be addressed.

Ireland: Actual and Structural Tax Revenues, 1987-2014
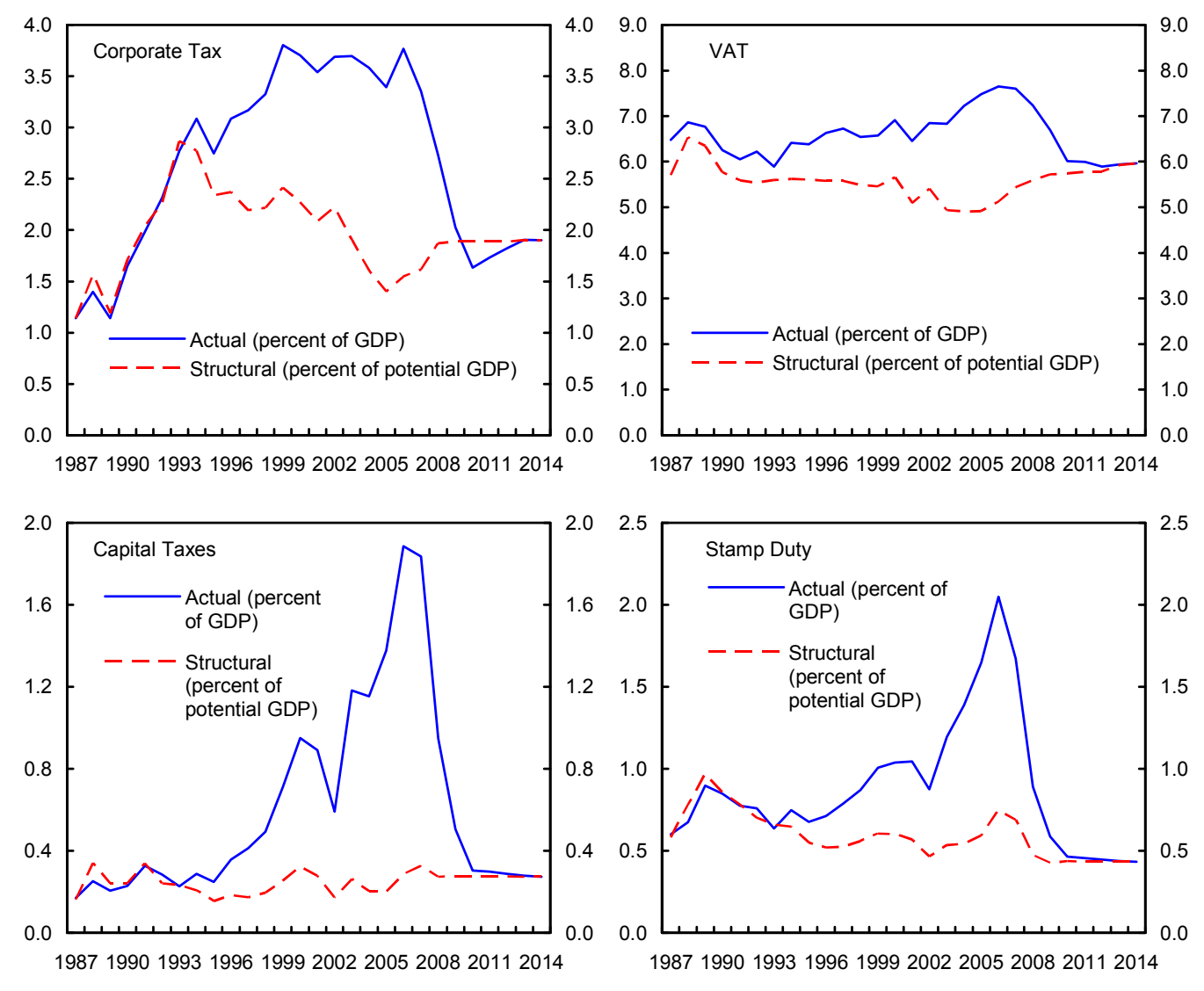

Sources: CSO, Department of Finance, and IMF staff calculations.

\section{A. The Consolidation Objectives and Debt Dynamics}

32. The authorities have embarked on a substantial consolidation plan. Following the sharp deceleration of growth and revenues, the fiscal deficit threatened to reach 15 percent of GDP, which compares with Ireland's record 171/2 percent of GDP in 1978. In a series of steps, the authorities have taken significant consolidation measures: revenue measures of about 1 percent of GDP — with the bulk coming from a levy on personal incomes — were announced 
with the original 2009 budget in October 2008; expenditure savings of a further 1 percent of GDP, centered on reducing the public service wage bill through a pension levy for public sector workers were announced in February 2009; and, finally, a supplementary budget was unveiled on April 7 (Text Table 2). Based on these measures, the authorities project deficits of $10^{3} / 4$ percent of GDP in 2009 and 2010, with a goal of reaching below 3 percent of GDP by 2013. Because of weaker growth projections and also continued lowering of the price level in 2010, staff projects deficits of $11 \frac{3}{4} 4$ percent of GDP in 2009 and $12^{3 / 4}$ percent in 2010.

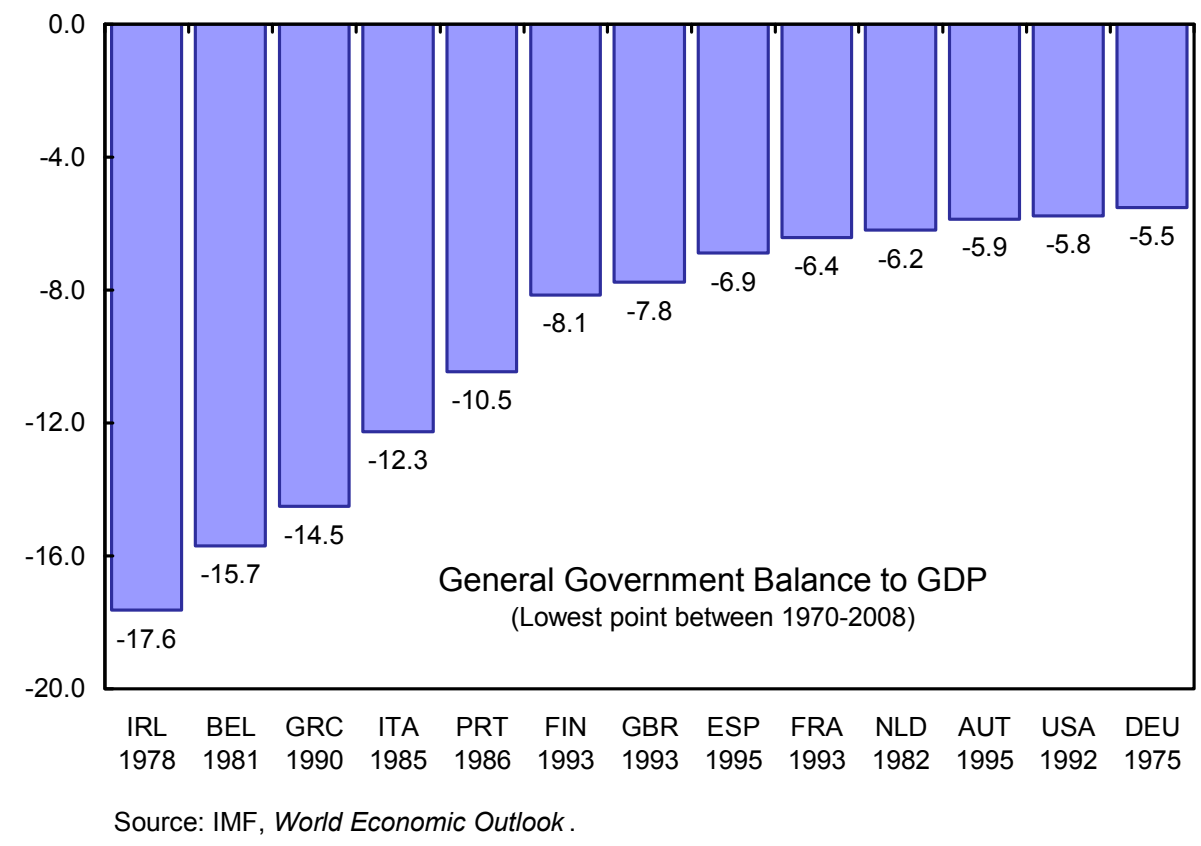

\section{The basic approach and elements of the plan are appropriate.}

- $\quad$ Measures thus far focus more on tax increases, particularly on the middleand upper-income earners. In the context of the severe ongoing downturn, it reduces the contractionary effect of the consolidation while also protecting the more vulnerable households. Moreover, it begins a necessary process of returning tax rates to more normal levels.

Text Table 2. April 2009 Supplementary Budget: Key Measures

\begin{tabular}{lrc}
\hline & \multicolumn{2}{c}{ Yield in 2009 } \\
\cline { 2 - 3 } & Millions of Euros & Percent of GDP \\
\hline Revenue & 1,007 & 0.6 \\
Tax & 754 & 0.4 \\
Personal income tax & -2 & 0.0 \\
VAT & 30 & 0.0 \\
Capital gains tax & 31 & 0.0 \\
Capital acquisitions tax & 110 & 0.1 \\
Stamp duties & 84 & 0.0 \\
$\quad$ Excise duties & 799 & 0.5 \\
Social contributions & 1,806 & 1.1 \\
Gross revenue yield & -577 & -0.3 \\
Negative impact of measures on activity & 1,229 & 0.7 \\
Net revenue yield & -886 & -0.5 \\
Current expenditure & -576 & -0.3 \\
Capital expenditure & 2,691 & 1.6 \\
Total impact on fiscal balance &
\end{tabular}

Source: Department of Finance. 
- In the following years, the goal is to rely more on expenditure, particularly on current expenditure cuts, in line with the empirical evidence on their importance of sustaining consolidations and even providing some expansionary benefits.

\section{Staff's baseline implies stronger expenditure consolidation than that currently} projected by the authorities to reach their goals. Starting from a higher projected deficit in 2009 and using a more pessimistic forecast for revenues, staff's baseline deficit in 2013 would be 4 percent of GDP versus the authorities target of $2 \frac{1}{2}$ percent of GDP in that year. A further plausible consolidation in 2014 would bring the deficit below the authorities' target to $1 \frac{1}{2}$ percent of GDP. In sum, over 2009-14, staff's baseline would imply that primary expenditures are brought down by $9 \frac{1}{2}$ percent of GDP while revenue measures of about $33 / 4$ percent of GDP would offset further declines in property-related taxes and raise overall revenues by about $2 \frac{1}{2}$ percent of GDP.

35. Public debt would stabilize at relatively high levels. Excluding the costs likely to be incurred for supporting the financial system, staff's consolidation path would stabilize the public debt at over 80 percent of GDP by 2014, only somewhat higher than that of the authorities' target of 77 percent of GDP by 2013. Reducing the deficit to zero and, especially, reducing debt to below the Maastricht ceiling of 60 percent of GDP would require much deeper measures than currently envisaged (Figure 5 and Appendix I). The debt to be incurred to support the financial sector remains uncertain. If the losses suffered by banks are about 20 percent of GDP, as estimated by staff, then bank recapitalization needs could be around 12-15 percent of GDP. Gross public debt could rise by about that much. The authorities and staff agreed assets would be acquired against this debt and the approach to consolidation would remain largely the same.

36. Financing needs are substantial in the near term. Financing needs for the fiscal deficit and public debt rollover are projected at about $€ 25$ billion for 2009 and $€ 22$ billion for 2010. Having issued bonds to the tune of about $€ 12$ billion since the start of the year, the authorities currently have about $€ 25$ billion in cash balances plus about $€ 15$ billion in liquid assets in the NPRF. The authorities have used some part of the NPRF resources towards the recapitalization of banks. In addition, through their guarantee, the authorities will also support the rollover of banks short-term debt. 
Figure 5. Ireland: Alternative Fiscal Scenarios
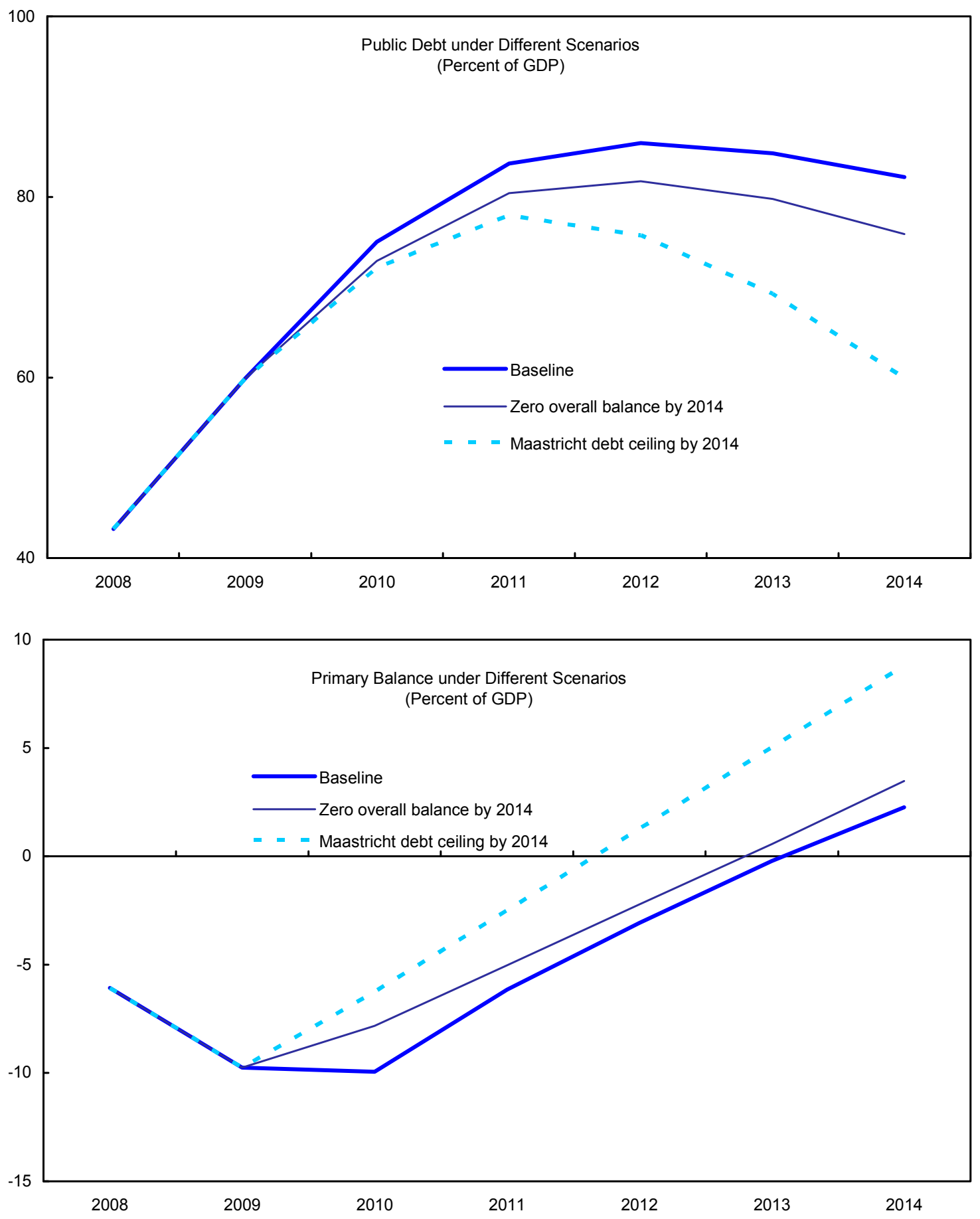

Source: IMF, staff calculations. 


\section{B. Consolidation Strategies}

37. The international evidence is clear: fiscal adjustment should focus on expenditure cuts. While there remains scope to raise tax rates and especially to broaden the base, the rapid growth in Irish public expenditure relative to other countries in the OECD, creates scope for significant fiscal expenditure cuts in Ireland. The authorities and staff agreed that episodes of large fiscal adjustments that focused on expenditure cuts-particularly the wage bill and social transfershave been better sustained than tax-based consolidations and have often been expansionary rather than contractionary.

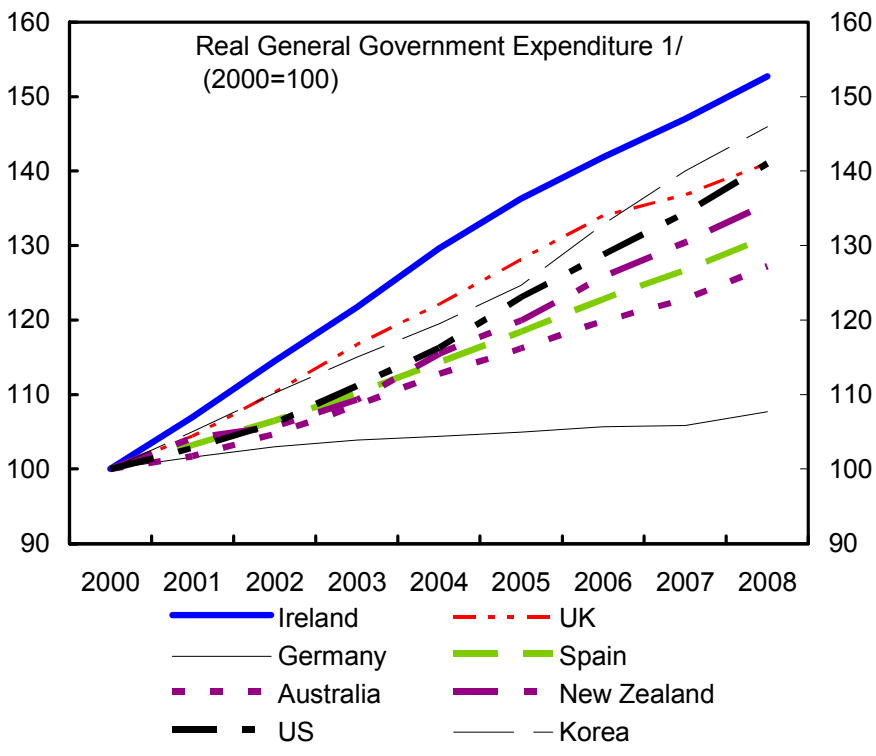

Source: Haver Analytics. 1/ Central Government data were used for Korea.

38. Social welfare expenditures must better target the vulnerable. The authorities recognize that it will be necessary to articulate a strategy that moves away from universalism in social welfare to one that relies more on targeting and incentives. In this regard, means testing or taxation of child benefits is under discussion. Consideration could also be given to earned income tax credits as a way of supporting lower income families, as also to the indexing of benefits to more appropriate price baskets. Also, a more nuanced minimum wage structure that allows, for example, for age-related differentials could help competitiveness and also reduce social transfers.

39. Despite the recent reduction further cuts in the public service wage bill are likely to be inevitable. Public sector remuneration now lies above private sector levels in most areas. In 2006, the Economic and Social Research Institute concludes, the public sector pay premium was above 20 percent. International comparisons also suggest that public sector wages in Ireland are higher than in other advanced economies. The authorities noted that an effective wage reduction of 7.5 percent was undertaken earlier this year by the application of the pension levy, and a wage freeze is in effect through 2010, but agreed with staff that consolidation on the scale needed is unlikely to be accomplished without a further lowering of the public wage bill. 
40. A review of public service employment is needed. Between 2000 and 2008, while total employment grew at an annual rate of 3 percent, public administration and defense employment grew at 3.7 percent. Employment growth in governmentprovided health and education services was even higher. This was triggered in part by the demand for more and better health and educational services by a wealthier Irish population. However, the authorities agreed that evaluating the scope of government

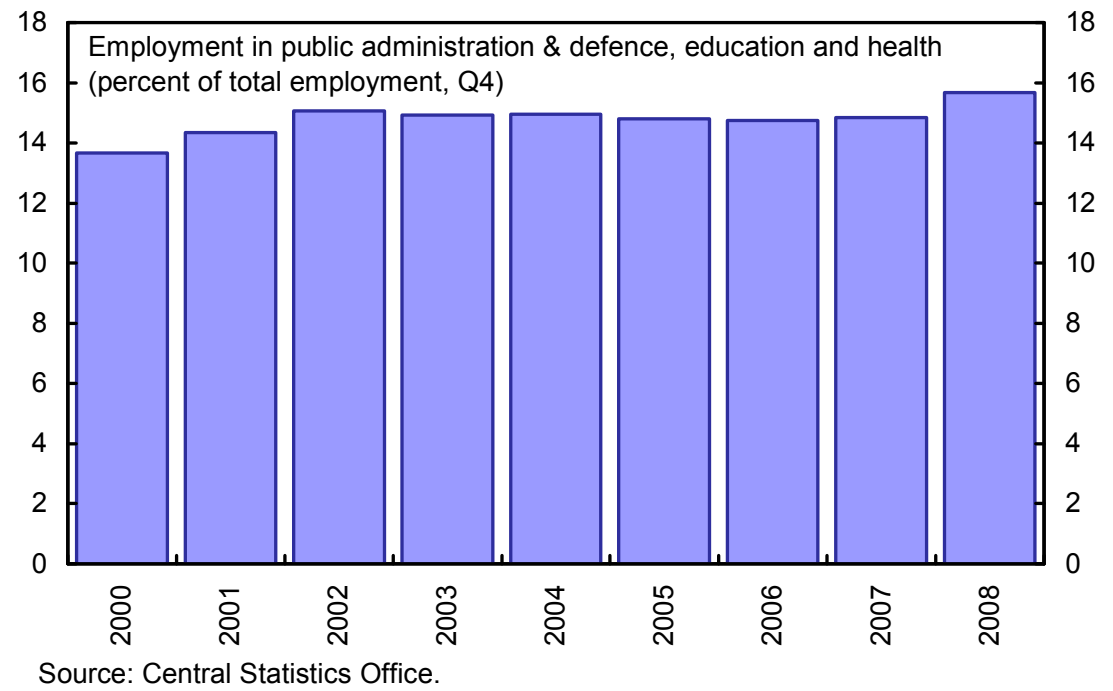
provision and its cost effectiveness is called for. More generally, greater efforts to obtain value for money are going to be important.

41. On the tax side, broadening the base is the key challenge. As noted by the OECD, Ireland has steadily increased tax relief on mortgage interest payments while having virtually no property taxation. In combination, these have generated strong incentives for home ownership and encouraged the housing boom. The authorities noted that the recent budget took steps toward limiting tax relief on mortgage interest and signaled the likely introduction of property taxation. While long overdue, significant administrative challenges arise in the implementation of property taxation. In this regard, staff suggested that Ireland has scope for raising social security contributions, even recognizing that this would raise the tax wedge. Staff concurred with the authorities that given the already high VAT rates, there were limits to raising revenues through indirect taxes.

\section{To stay on course, the proposed consolidation will require robust institutional}

support. The work of the Commission on Taxation and the Special Group of Public Service Numbers and Expenditure Programs will be important. In this regard, a fiscal rule can create the basis of a public commitment to fiscal prudence. This would be valuable for navigating the ongoing politically-sensitive consolidation and maintaining long-term fiscal policy stability. In the context of the European Union's Stability and Growth Pact, a statutory commitment to a medium-term objective of close to structural balance would be appropriate. This would need to be supported by a medium-term expenditure framework that outlines a detailed time path of expenditure reductions. Transparency and mechanisms to ensure the review of these objectives would limit the risk that they are diluted. While the authorities were supportive of such a rules-based framework, they were less sure of how quickly it could be implemented. 


\section{Staff Appraisal}

43. The Irish economy is in the midst of an unprecedented economic correction. The stress exceeds that being faced currently by any other advanced economy and matches episodes of the most severe economic distress in post-World War II history. Banks face extensive losses and double-digit fiscal deficits over the next three years will imply a run up in public debt. The short-term dislocations come on top of a sharp decline in potential growth, implying a modest pace of recovery.

44. The risks remain significant. Market sentiment has improved and Irish sovereign spreads have come down from their highs. The reduction in public sector wages has been accompanied by a decline in private wages, which if sustained would help competitiveness in the medium term. But the recent research is clear. Financial crises generate deeper and more prolonged downturns, and more so if the crisis is globally synchronized. In a weakened Irish economy, adverse global economic and financial events would be disruptive.

45. On the two fronts that matter most, the authorities have moved in the right direction. Most recently, the proposed establishment of NAMA offers the prospect of extracting distressed assets from the banks, a precondition for their return to healthy functionality. They have also laid out a multi-year plan to contain the fiscal deficit.

\section{But the task ahead is formidable and determined execution of these initiatives} will be needed. The challenge is severe because unwinding the large macroeconomic imbalances entails difficult policy trade-offs, which, in turn, are associated with considerable political sensitivities. Communicating clear objectives, allowing for contingencies, and creating benchmarks for transparent assessment will help maintain political legitimacy.

47. With regard to NAMA, risk-sharing structures should be considered to address the well-known pricing problem. The pricing of distressed assets is complex and can slow down the transfer of assets from the troubled bank. Risk-sharing can potentially create better incentives for managing the bad assets. And they also guard against the risk that the taxpayer does not bear a disproportionate burden of the costs cleaning up the banks.

48. It is particularly important to incorporate flexibility in NAMA's design. While an early focus on removing property-development loans from the financial system may be appropriate, the economic downturn will cause impairment of other asset classes as the latest trends are already indicating. The option of relieving banks of those additional assets within a year or so will continue the process of "cleaning" up the banks. Absent that option, banks may remain hobbled.

49. Where a bank has been rendered economically insolvent, the only real option would be its temporary nationalization. In that case, NAMA would continue to act in its capacity as an agency managing bad assets. An advantage would be that prices at which these 
assets are transferred would become less of an issue. Nationalization could also be used as a step towards mergers and, hence, sectoral restructuring. But it would be necessary to ensure that the banks are operated transparently, with commercial objectives, and that they receive the same regulatory and supervisory treatment as private banks. Finally, a clear exit strategy to return the banks to private operation would be needed.

50. Accompanying these immediate crisis management tasks are several supportive crisis prevention measures. These can and should be guided by evolving European Union guidelines. However, inevitably, they will need to be tailored to domestic circumstances.

- A broader tool kit would allow for more speedy resolution of banks. This would be supported by the authorities' ongoing enhancements of the deposit protection program.

- $\quad$ The supervisory challenges include intensification of surveillance for systemic risks beyond the six guaranteed banks, further safeguards against related-party lending, and continued development of a macro-prudential regulatory and supervisory process.

51. The authorities have laid out an ambitious fiscal consolidation plan. While the initial reliance on increases in personal income tax rates was appropriate to minimize the contractionary effect of the consolidation, a greater focus on reductions in current expenditure will be needed in the coming years.

52. Steps should be taken to sustain the execution of the planned fiscal consolidation. The following principles could be used as a guide:

- $\quad$ More targeting of the vulnerable (as proposed for child benefits) and greater reliance on incentives for efficient use of public resources.

- $\quad$ Further ratcheting down of the public pay structure and employment levels.

- $\quad$ Broadening the tax base.

- A fiscal rule, backed by a medium-term expenditure plan that details the intended measures over the full horizon.

53. It is proposed that the next Article IV consultation be held on the standard 12-month cycle. 
Table 1. Ireland: Selected Economic Indicators

(Annual change unless otherwise stated)

\begin{tabular}{|c|c|c|c|c|c|c|c|c|}
\hline & \multirow[b]{2}{*}{2003} & \multirow[b]{2}{*}{2004} & \multirow[b]{2}{*}{2005} & \multirow[b]{2}{*}{2006} & \multirow[b]{2}{*}{2007} & \multicolumn{3}{|c|}{ Proj. } \\
\hline & & & & & & 2008 & 2009 & 2010 \\
\hline \multicolumn{9}{|l|}{ National accounts (constant prices) } \\
\hline GNP & 5.9 & 4.5 & 5.8 & 6.3 & 4.1 & -3.1 & -7.4 & -3.6 \\
\hline GDP & 4.5 & 4.7 & 6.4 & 5.7 & 6.0 & -2.3 & -8.5 & -3.0 \\
\hline Domestic demand & 3.9 & 4.3 & 8.7 & 6.1 & 3.7 & -5.7 & -11.5 & -6.0 \\
\hline Private consumption & 3.1 & 3.9 & 7.1 & 7.1 & 6.3 & -0.8 & -9.0 & -5.0 \\
\hline Public consumption & 1.3 & 1.5 & 2.9 & 4.8 & 6.0 & 2.1 & 0.7 & 0.6 \\
\hline Gross fixed investment & 5.5 & 9.1 & 14.1 & 4.0 & 1.2 & -19.9 & -25.4 & -14.8 \\
\hline Net exports $1 /$ & 1.5 & 0.4 & -1.3 & 0.2 & 2.6 & 2.7 & 1.9 & 1.9 \\
\hline Exports of goods and services & 0.6 & 7.5 & 5.2 & 5.7 & 6.8 & -0.4 & -6.0 & -1.5 \\
\hline Imports of goods and services & -1.6 & 8.5 & 8.2 & 6.3 & 4.1 & -4.4 & -10.2 & -4.8 \\
\hline Gross national saving (in percent of GDP) & 23.4 & 24.0 & 24.0 & 24.8 & 21.8 & 17.8 & 16.6 & 16.3 \\
\hline Private & 20.4 & 19.4 & 19.4 & 18.8 & 18.7 & 21.9 & 29.2 & 31.1 \\
\hline Public & 3.0 & 4.6 & 4.5 & 6.0 & 3.1 & -4.1 & -12.6 & -14.8 \\
\hline Gross investment (in percent of GDP) & 23.2 & 24.5 & 27.0 & 27.6 & 26.3 & 21.4 & 17.3 & 15.3 \\
\hline Private & 19.6 & 21.0 & 23.6 & 24.0 & 22.2 & 16.2 & 12.7 & 11.4 \\
\hline Public & 3.7 & 3.5 & 3.5 & 3.7 & 4.1 & 5.2 & 4.6 & 4.0 \\
\hline \multicolumn{9}{|l|}{ Prices, wages and employment } \\
\hline Harmonized Index of Consumer Prices (annual average) 2/ & 4.0 & 2.3 & 2.2 & 2.7 & 2.9 & 3.1 & -0.7 & .. \\
\hline Average wages, all economy & 5.0 & 5.9 & 5.1 & 5.5 & 5.2 & 3.6 & $\ldots$ & ... \\
\hline Output, manufacturing $3 /$ & 4.6 & 0.1 & 3.1 & 5.3 & 7.5 & 0.0 & -1.7 & ... \\
\hline GNP/employment & 4.0 & 1.3 & 0.9 & 1.7 & 0.6 & -2.5 & 0.6 & 1.5 \\
\hline Employment & 1.9 & 3.1 & 4.9 & 4.5 & 3.6 & -0.6 & -7.9 & -5.0 \\
\hline Unemployment rate (in percent) & 4.7 & 4.5 & 4.4 & 4.4 & 4.5 & 6.1 & 12.0 & 15.5 \\
\hline \multicolumn{9}{|l|}{ Money and credit (end-period) } \\
\hline M3 3/ & 9.8 & 22.5 & 22.0 & 28.5 & 9.6 & -2.1 & -5.0 & ... \\
\hline Private sector credit $3 / 4 /$ & 17.9 & 26.6 & 28.8 & 25.9 & 17.0 & 6.6 & 4.8 & ... \\
\hline \multicolumn{9}{|l|}{ Financial and asset markets (end-period) } \\
\hline Three-month treasury bill $2 /$ & 2.1 & 2.2 & 2.5 & 3.7 & 3.4 & 1.5 & 0.9 & ... \\
\hline 10-year government bond $2 /$ & 4.6 & 3.7 & 3.3 & 4.0 & 4.5 & 4.4 & 5.5 & ... \\
\hline ISEQ index 2/ & 12.2 & 26.8 & 16.8 & 27.8 & -26.3 & -66.2 & -64.5 & ... \\
\hline House prices (permanent tsb index/ESRI) $3 /$ & 13.7 & 8.6 & 9.3 & 11.8 & -7.3 & -9.1 & -9.7 & .. \\
\hline \multicolumn{9}{|l|}{ Public finance (in percent of GDP) } \\
\hline General government balance & 0.3 & 1.4 & 1.5 & 2.9 & 0.2 & -7.1 & -11.8 & -12.7 \\
\hline Primary balance & 1.5 & 2.5 & 2.5 & 3.8 & 1.2 & -6.1 & -9.8 & -10.0 \\
\hline General government debt & 31.1 & 29.4 & 27.3 & 24.7 & 24.8 & 43.2 & 59.9 & 75.0 \\
\hline \multicolumn{9}{|l|}{ External trade and balance of payments } \\
\hline Balance of goods and services (percent of GDP) & 15.4 & 14.2 & 11.7 & 10.3 & 10.3 & 11.5 & 14.5 & 16.3 \\
\hline Current account (percent of GDP) & 0.0 & -0.6 & -3.5 & -3.6 & -5.4 & -4.5 & -1.1 & 0.5 \\
\hline Official reserves (in billions of euros, end-period) & 3.3 & 2.1 & 0.7 & 0.6 & 0.6 & 0.7 & $\ldots$ & ... \\
\hline \multicolumn{9}{|l|}{ Effective exchange rates (1999Q1 $=100$, annual average $)$} \\
\hline Nominal & 101.9 & 104.5 & 104.1 & 104.4 & 107.4 & 113.0 & $\ldots$ & ... \\
\hline Real (CPI based) & 112.6 & 115.8 & 115.4 & 116.0 & 120.1 & 125.5 & $\ldots$ & .. \\
\hline \multicolumn{9}{|l|}{ Memorandum items: } \\
\hline Population (in millions) & 4.0 & 4.0 & 4.1 & 4.2 & 4.3 & 4.4 & 4.4 & 4.4 \\
\hline GDP per capita (in euros) & 35,037 & 36,828 & 39,230 & 41,815 & 43,928 & 41,998 & 37,656 & 36,053 \\
\hline
\end{tabular}

Sources: Department of Finance; Central Bank of Ireland; IMF, International Financial Statistics; Bloomberg; and Fund staff calculations.

1/ Contribution to growth. However, the data for exports and imports of goods and services are annual growth rates.

2/ As of March 2009

3/ As of February 2009.

4/ Adjusted change, which includes the effects of transactions between credit institutions and non-bank international financial companies and valuation effects arising from exchange rate movements. 
Table 2. Ireland: Summary of Balance of Payments

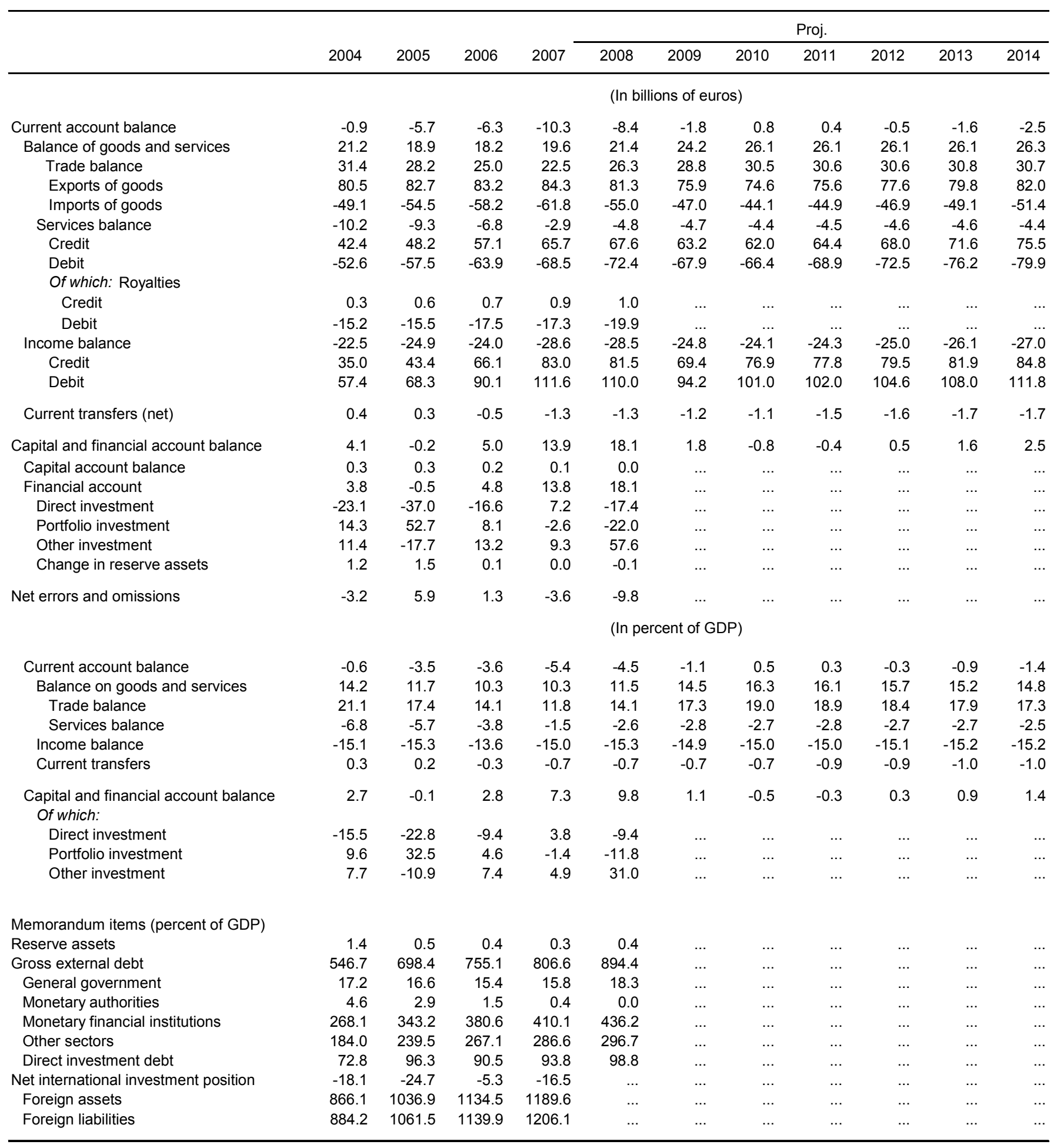

Sources: The Central Statistics Office; and Fund staff estimates. 
Table 3. Ireland: General Government Finances

(In percent of GDP)

\begin{tabular}{|c|c|c|c|c|c|c|c|c|c|c|}
\hline & \multicolumn{4}{|c|}{ Actual } & \multicolumn{6}{|c|}{ Staff Projections 1/ } \\
\hline & 2005 & 2006 & 2007 & 2008 & 2009 & 2010 & 2011 & 2012 & 2013 & 2014 \\
\hline Current balance & 5.0 & 6.5 & 4.7 & -1.1 & -6.8 & -8.4 & -5.3 & -2.6 & 0.1 & 2.5 \\
\hline Current revenue, of which: & 33.6 & 35.0 & 34.2 & 31.9 & 31.9 & 31.7 & 33.9 & 34.2 & 34.4 & 34.4 \\
\hline Tax revenue (including taxes on capital) & 25.7 & 27.0 & 26.0 & 23.1 & 22.0 & 21.4 & 23.6 & 23.9 & 24.1 & 24.1 \\
\hline Income tax & 7.1 & 7.0 & 7.1 & 7.1 & 7.7 & 8.5 & 9.1 & 9.3 & 9.3 & 9.3 \\
\hline Excise duty & 3.3 & 3.2 & 3.1 & 2.9 & 2.9 & 2.8 & 2.9 & 3.0 & 3.1 & 3.1 \\
\hline Capital taxes & 1.4 & 1.9 & 1.8 & 0.9 & 0.5 & 0.3 & 0.3 & 0.3 & 0.3 & 0.3 \\
\hline Stamp duty & 1.6 & 2.0 & 1.7 & 0.9 & 0.6 & 0.5 & 0.5 & 0.4 & 0.4 & 0.4 \\
\hline Other taxes & 1.4 & 1.5 & 1.3 & 1.2 & 1.5 & 1.6 & 3.1 & 3.1 & 3.1 & 3.1 \\
\hline Social security receipts & 4.5 & 4.6 & 4.7 & 5.0 & 5.0 & 5.0 & 5.0 & 5.0 & 5.0 & 5.0 \\
\hline Miscellaneous & 3.3 & 3.3 & 3.4 & 3.9 & 4.9 & 5.3 & 5.3 & 5.3 & 5.3 & 5.3 \\
\hline Current transfers & 12.4 & 12.6 & 13.0 & 15.0 & 18.9 & 19.2 & 18.2 & 16.6 & 15.0 & 13.4 \\
\hline Depreciation & 0.9 & 0.9 & 0.9 & 1.0 & 1.3 & 1.5 & 1.6 & 1.4 & 1.3 & 1.1 \\
\hline Primary current expenditure & 27.6 & 27.6 & 28.5 & 31.9 & 36.6 & 37.4 & 35.9 & 33.2 & 30.6 & 28.2 \\
\hline Capital balance & -3.5 & -3.5 & -4.5 & -6.1 & -5.0 & -4.2 & -4.2 & -4.1 & -4.0 & -3.9 \\
\hline Capital receipts (excluding taxes on capital) & 0.9 & 1.1 & 0.9 & 1.0 & 1.0 & 1.0 & 1.0 & 1.0 & 1.0 & 0.9 \\
\hline Gross capital formation & 3.5 & 3.7 & 4.1 & 5.2 & 4.6 & 4.0 & 4.0 & 4.0 & 4.0 & 4.0 \\
\hline Capital transfers & 0.9 & 1.0 & 1.3 & 1.9 & 1.4 & 1.3 & 1.2 & 1.1 & 1.0 & 0.9 \\
\hline General government balance & 1.5 & 2.9 & 0.2 & -7.1 & -11.8 & -12.7 & -9.4 & -6.7 & -3.9 & -1.4 \\
\hline Primary balance & 2.5 & 3.8 & 1.2 & -6.1 & -9.8 & -10.0 & -6.2 & -3.1 & -0.2 & 2.3 \\
\hline Growth in nominal GDP & 8.9 & 9.3 & 7.5 & -2.6 & -10.1 & -4.0 & 1.0 & 2.5 & 3.3 & 3.5 \\
\hline
\end{tabular}

Sources: Department of Finance; and staff estimates.

1/ Staff projections are based on the 2009 supplementary budget, adjusted for staff's macroeconomic and revenue buoyancy assumptions. 2/ Net debt is defined as gross debt minus the value of the National Pensions Reserve Fund and the Social Insurance Fund. 
Table 4. Ireland: Medium-Term Scenario

(Percentage change, unless otherwise indicated)

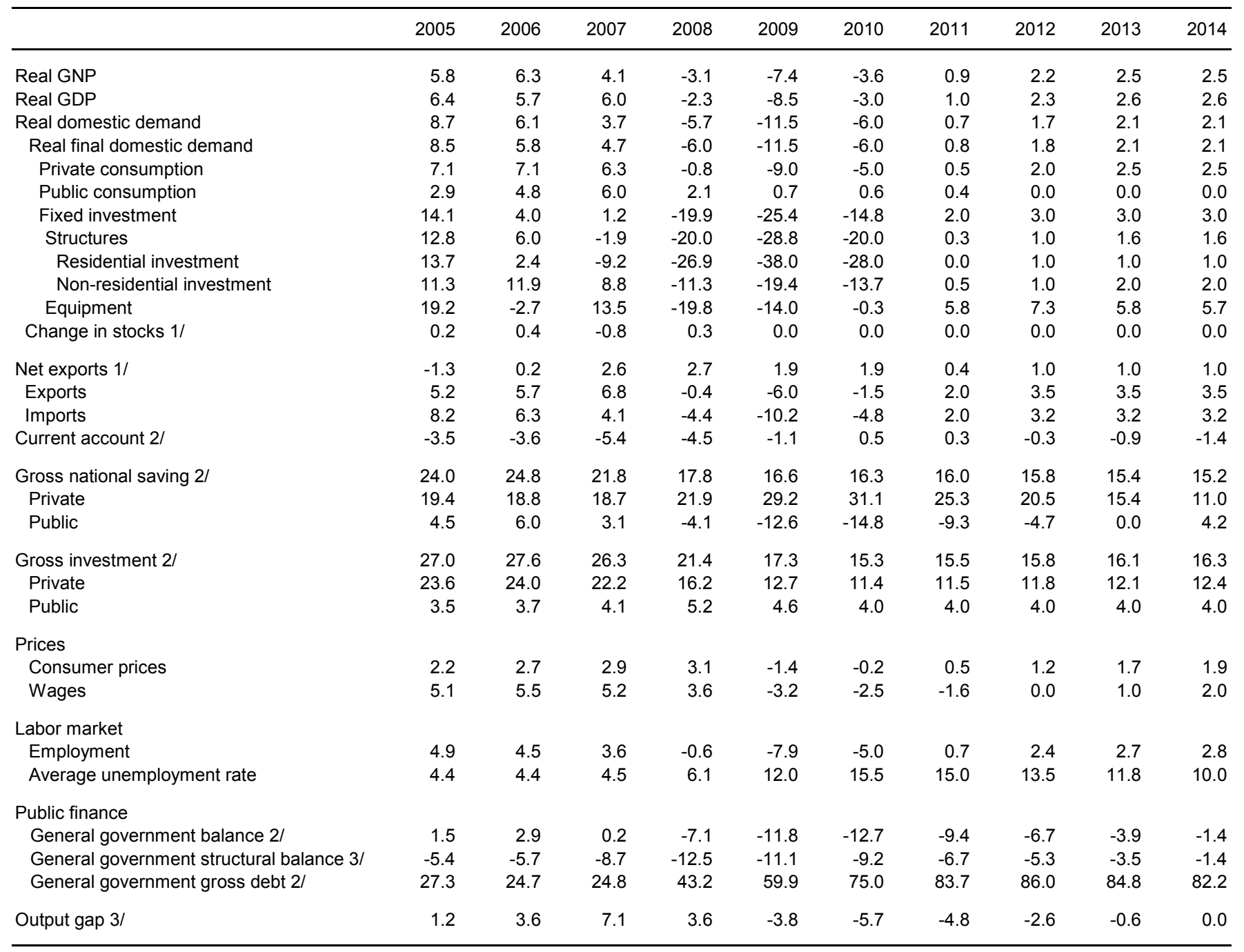

Sources: CSO; Department of Finance; and IMF staff calculations.

$1 /$ Contributions to growth.

2/ In percent of GDP.

$3 /$ In percent of potential output. 
Table 5. Sectoral Developments in Private-Sector Credit

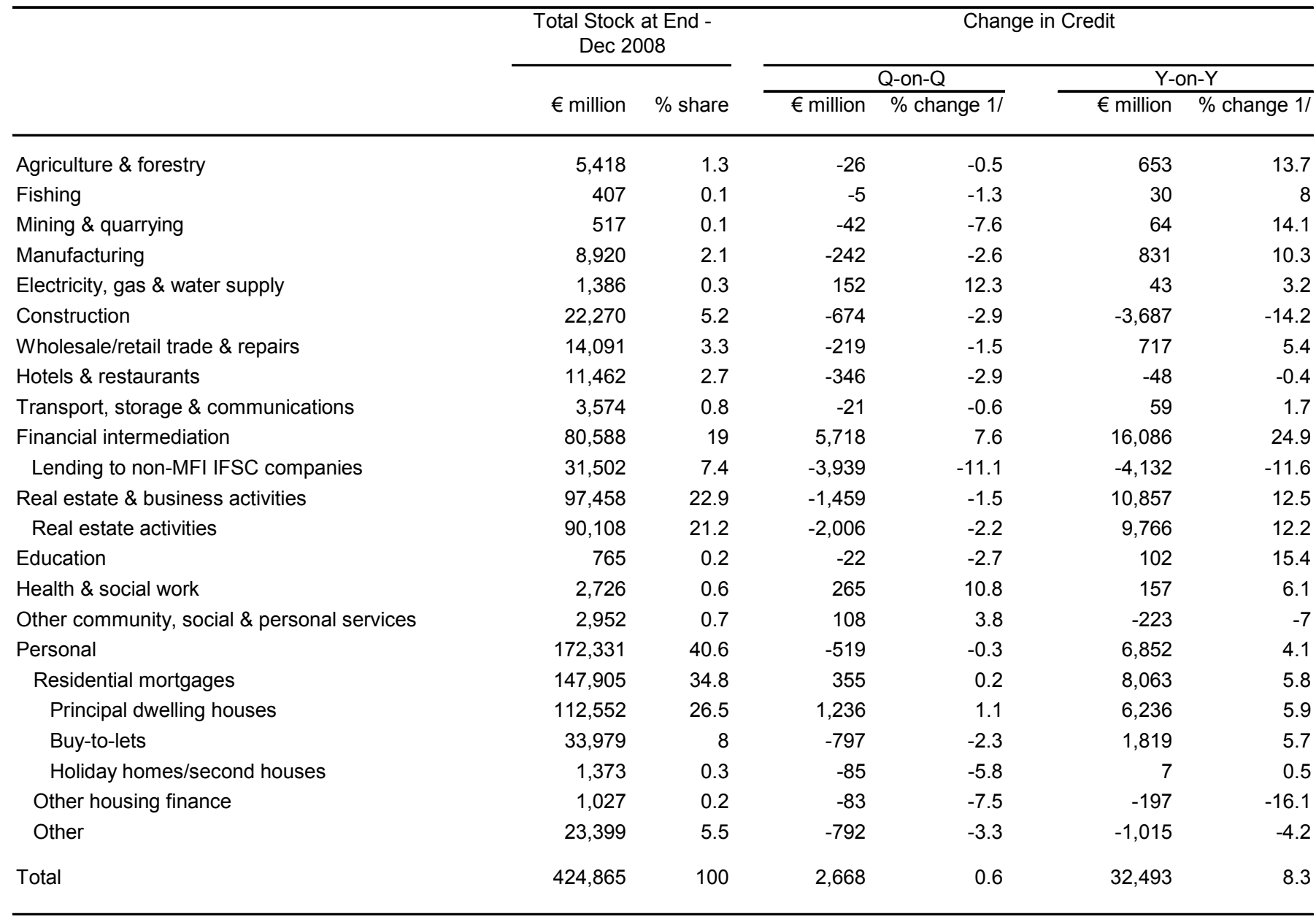

Source: CBFSAI.

$1 /$ The growth rates are inclusive of securitised residential mortgages, but are not adjusted for accrued interest, lending to the IFSC or exchange-rate valuation effects. 
Table 6. Ireland: Indicators of External and Financial Vulnerability

\begin{tabular}{|c|c|c|c|c|c|c|c|c|c|}
\hline & 2000 & 2001 & 2002 & 2003 & 2004 & 2005 & 2006 & 2007 & 2008 \\
\hline \multicolumn{10}{|l|}{ External indicators } \\
\hline Exports (annual percent change, value in euros) & 10.7 & 9.9 & 10.8 & 14.2 & 17.1 & 6.7 & 8.0 & 16.7 & 6.6 \\
\hline Imports (annual percent change, value in euros) & 13.2 & 7.6 & 7.0 & 13.1 & 19.1 & 10.3 & 9.9 & 16.6 & 4.9 \\
\hline Terms of trade (goods, annual percent change) & -3.6 & 2.4 & 2.1 & -0.5 & -1.4 & 1.2 & -4.6 & -3.3 & $\ldots$ \\
\hline Current account balance (in percent of GDP) & -0.4 & -0.6 & -1.0 & 0.0 & -0.6 & -3.5 & -3.6 & -5.4 & -4.5 \\
\hline Capital and financial account balance (in percent of GDP) & 9.2 & 0.3 & 1.2 & -0.9 & 2.7 & -0.1 & 2.8 & 7.3 & 9.8 \\
\hline \multicolumn{10}{|l|}{ Of which: } \\
\hline Inward portfolio investment & 80.0 & 84.9 & 57.7 & 75.1 & 100.3 & 107.0 & 125.0 & 84.8 & $\ldots$ \\
\hline Inward foreign direct investment & 26.7 & 9.2 & 23.9 & 14.5 & -5.7 & -15.7 & -2.5 & 11.7 & $\ldots$ \\
\hline Other investment liabilities & 29.3 & 36.9 & 40.2 & 57.3 & 39.8 & 57.7 & 74.5 & 89.5 & $\ldots$ \\
\hline Total external public debt (in percent of GDP) 1/ & 2.0 & 1.8 & 0.6 & 0.0 & 0.0 & 0.0 & 0.0 & 0.0 & 0.0 \\
\hline \multicolumn{10}{|l|}{ Of which: } \\
\hline External debt to exports ratio (in percent) & 2.6 & 2.4 & 0.8 & 0.0 & 0.0 & 0.0 & 0.0 & 0.0 & 0.0 \\
\hline External interest payments to exports (in percent) & 0.2 & 0.1 & 0.2 & 0.0 & 0.0 & 0.0 & 0.0 & 0.0 & 0.0 \\
\hline U.S. dollar per euro (period average) & 0.92 & 0.90 & 0.94 & 1.13 & 1.24 & 1.25 & 1.26 & 1.37 & 1.47 \\
\hline U.K. pound per euro (period average) & 0.61 & 0.62 & 0.63 & 0.69 & 0.68 & 0.68 & 0.68 & 0.68 & 0.79 \\
\hline \multicolumn{10}{|l|}{ Financial markets indicators } \\
\hline General government debt (in percent of GDP) & 37.8 & 35.5 & 32.2 & 31.1 & 29.4 & 27.3 & 24.7 & 24.8 & 43.2 \\
\hline Government bond yield (in percent, 10-year, end-period) & 5.1 & 5.1 & 4.3 & 4.6 & 3.7 & 3.3 & 4.0 & 4.5 & 4.4 \\
\hline Spread of government bond yield with Germany (in percent, end of period) & 0.2 & 0.4 & 0.0 & 0.3 & 0.1 & -0.1 & 0.2 & 0.0 & 0.0 \\
\hline Real government bond yield (in percent, 10 -year, period average, based on $\mathrm{CPI}$ ) & -0.4 & 0.9 & 0.0 & 2.1 & 1.4 & 1.0 & -1.1 & 0.1 & 0.0 \\
\hline Annual change in ISEQ index (in percent, end of period) & 18.0 & -5.7 & -18.8 & 12.2 & 26.8 & 16.8 & 27.8 & -26.3 & -66.2 \\
\hline Personal lending interest rate (in percent) & 11.8 & 10.6 & 10.4 & 9.9 & 9.9 & 10.1 & 11.2 & 11.7 & 12.0 \\
\hline Variable mortgage interest rate (in percent) & 6.0 & 4.6 & 4.2 & 3.5 & 3.5 & 3.6 & 4.8 & 5.4 & 5.3 \\
\hline \multicolumn{10}{|l|}{ Financial sector risk indicators } \\
\hline Annual credit growth rates (to private sector, in percent) & 21.3 & 15.1 & 15.0 & 17.9 & 26.6 & 28.8 & 25.9 & 17.0 & 6.6 \\
\hline Annual deposit growth rates (in percent) & 15.6 & 15.6 & 9.6 & 11.9 & 14.1 & 25.4 & 23.6 & 11.9 & -3.4 \\
\hline $\begin{array}{l}\text { Personal lending as a share of total loans (in percent) } \\
\text { (excluding financial intermediation and government) }\end{array}$ & 52.1 & 52.2 & 55.3 & 55.6 & 55.8 & 54.6 & 50.3 & $\ldots$ & $\ldots$ \\
\hline \multicolumn{10}{|l|}{ Of which: } \\
\hline House mortgage finance & 39.0 & 38.8 & 42.4 & 44.4 & 44.9 & 44.6 & 41.5 & $\ldots$ & $\ldots$ \\
\hline Other housing finance & 1.0 & 0.9 & 0.8 & 0.4 & 0.3 & 0.3 & 0.4 & $\ldots$ & $\ldots$ \\
\hline Other personal lending & 12.2 & 12.5 & 12.0 & 10.8 & 10.6 & 9.7 & 8.4 & $\ldots$ & $\ldots$ \\
\hline Annual mortgage credit growth rates (in percent) & 24.3 & 17.8 & 23.1 & 25.5 & 26.5 & 27.1 & 24.2 & $\ldots$ & $\ldots$ \\
\hline \multicolumn{10}{|l|}{ Commercial property lending as a percent of total loans } \\
\hline (excluding financial intermediation) $2 /$ & 15.0 & 16.4 & 17.0 & 19.7 & 21.2 & 25.3 & 31.2 & $\ldots$ & \\
\hline Foreign-currency denominated assets (in percent of total assets) & 41.5 & 44.6 & 40.1 & 32.5 & 29.4 & 33.9 & 33.7 & 36.5 & 32.2 \\
\hline Foreign-currency denominated liabilities (in percent of total liabilities) & 44.4 & 47.4 & 42.9 & 34.2 & 32.2 & 35.9 & 36.9 & 41.1 & 36.0 \\
\hline Contingent and off-balance sheet accounts (in percent of total assets) $3 /$ & 465 & 592 & 505 & 538 & 662 & 879 & 1133 & & $\ldots$ \\
\hline Non-performing loans (in percent of total loans) $4 /$ & 1.03 & 1.03 & 0.97 & 0.93 & 0.82 & 0.68 & 0.71 & 0.79 & $\ldots$ \\
\hline Total provisions for loan losses (in percent of total loans) & 1.1 & 1.1 & 1.1 & 0.9 & 0.7 & 0.5 & 0.4 & 0.4 & $\ldots$ \\
\hline Risk-weighted capital/asset ratios of domestic banks (in percent) & 10.7 & 10.6 & 12.3 & 13.9 & 12.6 & 12.0 & 10.9 & 10.7 & 10.6 \\
\hline Bank return on assets (before tax, in percent) & 1.2 & 0.9 & 1.0 & 0.9 & 1.1 & 0.8 & 0.8 & 0.7 & $\ldots$ \\
\hline Bank return on equity (before tax, in percent) & 22.0 & 16.0 & 18.0 & 17.8 & 20.7 & 19.6 & 19.1 & 16.4 & $\ldots$ \\
\hline Liquid assets of all banks to total assets (liquid asset ratio, in percent) & 32.0 & 30.0 & 30.0 & 33.6 & 33.0 & 34.2 & 32.7 & 28.4 & $\ldots$ \\
\hline Liquid assets of all banks to short-term liabilities (in percent) & 44.0 & 37.0 & 34.0 & 41.2 & 40.0 & 40.2 & 38.4 & 34.4 & \\
\hline Deposits to $\mathrm{M} 3$ ratio $5 / 6 /$ & 1.03 & 1.02 & 1.02 & 1.46 & 1.41 & 1.45 & 1.40 & 1.43 & 1.41 \\
\hline Loan-to-deposit ratio vis-à-vis Irish residents 2/ 7/ & 1.36 & 1.44 & 1.43 & 1.46 & 1.61 & 1.77 & 1.87 & 2.08 & 2.29 \\
\hline vis-à-vis total $2 / 7 /$ & 1.54 & 1.59 & 1.51 & 1.57 & 1.72 & 1.82 & 1.85 & 2.05 & 2.22 \\
\hline \multicolumn{10}{|l|}{ Concentration ratios in the banking sector } \\
\hline No. of banks accounting for 25 percent of total assets & 3.0 & 3.0 & 3.0 & 2.0 & 2.0 & 2.0 & 3.0 & 3.0 & 2.0 \\
\hline No. of banks accounting for 75 percent of total assets & 23.0 & 21.0 & 19.0 & 18.0 & 17.0 & 16.0 & 17.0 & 15.0 & 14 \\
\hline Share of state-owned banks in total assets (in percent) & 2.0 & 1.0 & 0.0 & 0.0 & 0.0 & 0.0 & 0.0 & 0.0 & 0.0 \\
\hline Share of foreign-owned banks in total assets (in percent) & 39.0 & 42.0 & 29.0 & 31.0 & 34.0 & 32.3 & 36.3 & 32.2 & $\ldots$ \\
\hline
\end{tabular}

Sources: Data provided by the authorities; Central Bank of Ireland; International Financial Statistics; Bloomberg; and Fund staff estimates. $1 /$ Represents non-euro debt of the government sector.

$2 /$ Includes lending for construction and real estate activities.

$3 /$ Credit equivalent values.

4/ Owing to differences in classification, international comparisons of nonperforming loans are indicative only.

5/ Non-government deposits vis-à-vis Irish and nonresidents to M3 ratio.

6/ The methodology used to compile M3 has been amended in line with Eurosystem requirements. Therefore, there is a break in the series.

7/ Nongovernment loans/nongovernment deposits ratio. 


\section{APPENDIX I. IRELAND: SUSTAINABILITY EXERCISE}

\section{Fiscal Sustainability}

1. General government gross debt is set to rise sharply over the medium term as a result of the deterioration of the fiscal position. Under the baseline scenario, gross debt rises from 43 percent of GDP in 2008 to 82 percent of GDP by 2014 as the primary balance is projected to remain in deficit through 2013 and GDP growth is expected to be below the average real interest rate throughout this period.

2. The sustainability of the fiscal position over the next five years is assessed under alternative scenarios regarding key macroeconomic and fiscal assumptions, as well as several bound tests (Table A1 and Figure A1). The analysis shows that significant policy changes are required to entrench fiscal sustainability. The worst outcome - a rise in the debt ratio to 114 percent in 2014 - is achieved under the assumption of a constant primary balance.

\section{External Sustainability}

3. With a net external position (excluding direct investment) in balance in 2007, external debt sustainability does not seem to be an issue (Table A2). The net external position including direct investment is in a moderate deficit given the strong FDI inflows into Ireland over the past decade. The relatively rapid decline in the net external position in recent years has been dominated by factors other than the current account deficit, such as revaluations. The large gross assets and liabilities in portfolio and other investments reflect the activities of the International Financial Services Center.

4. The composition of the external position implies a large negative net income flow in the current account. The large stock of inward foreign direct investment, which reflects the substantial presence of multinationals, earns a high rate of return (about 21 percent on average during 2000-07). 
Figure A1. Ireland: Public Debt Sustainability: Bound Tests 1/

(Public debt in percent of GDP)
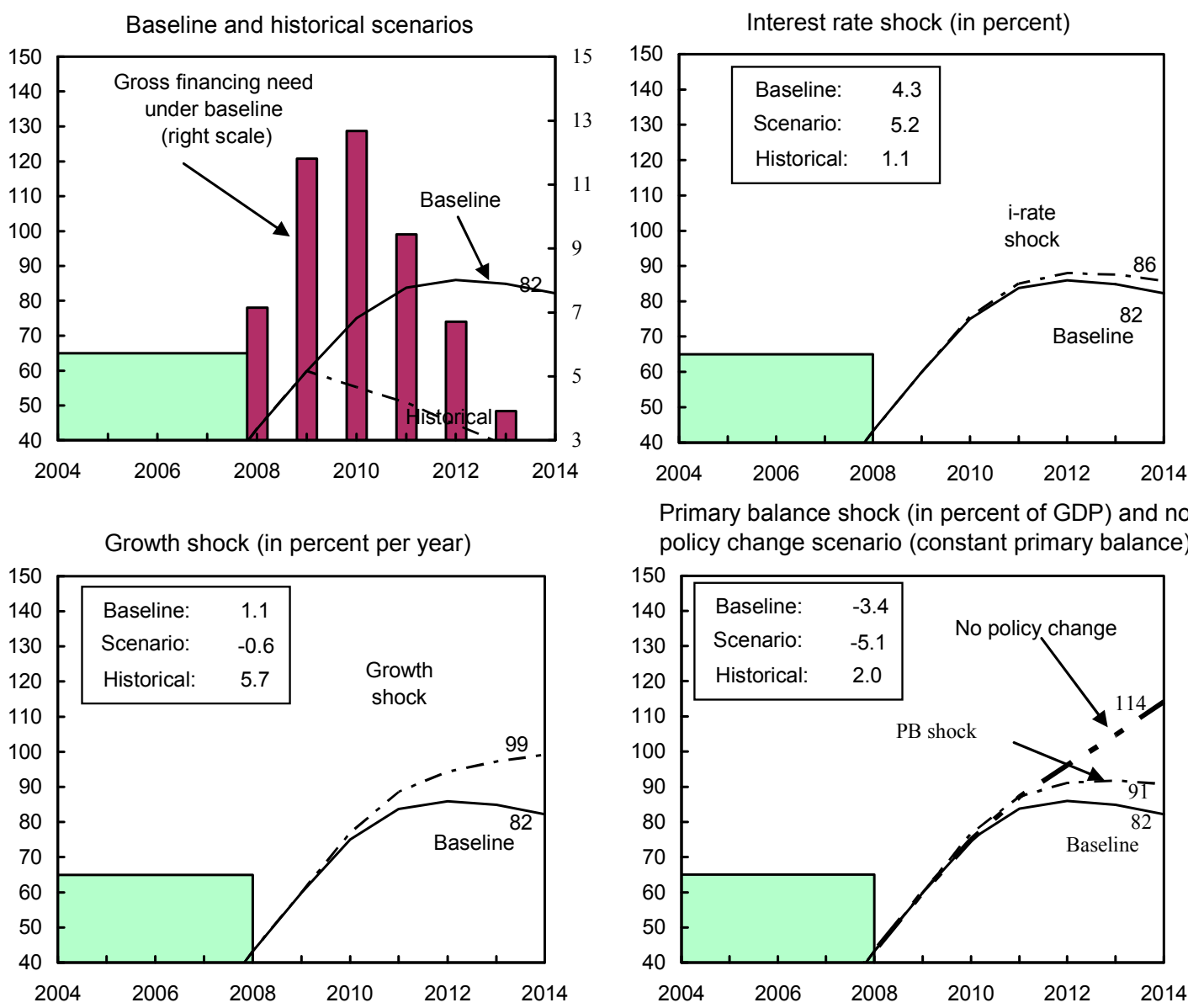

Primary balance shock (in percent of GDP) and no policy change scenario (constant primary balance)

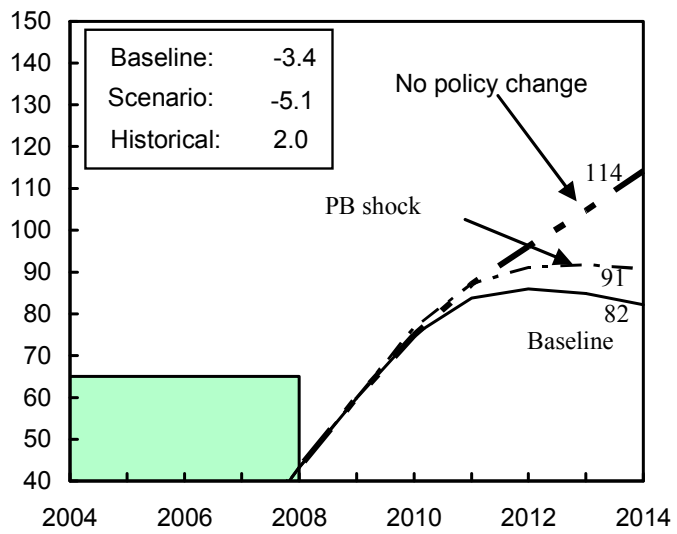

Combined shock $2 /$

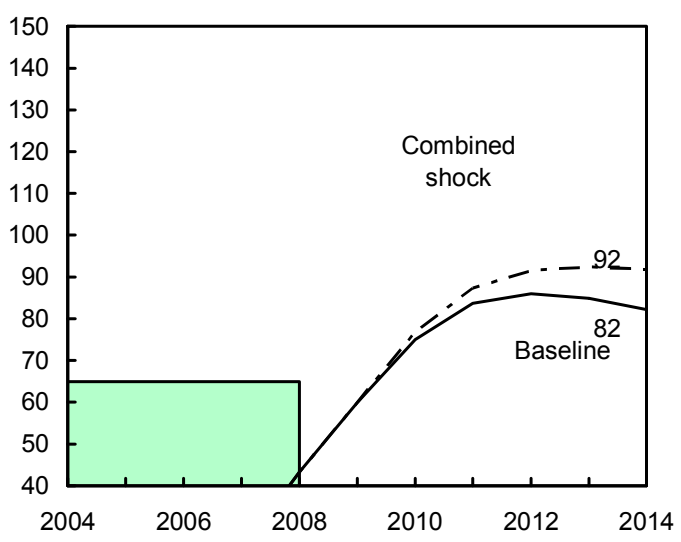

Real depreciation and contingent liabilities shocks $3 /$

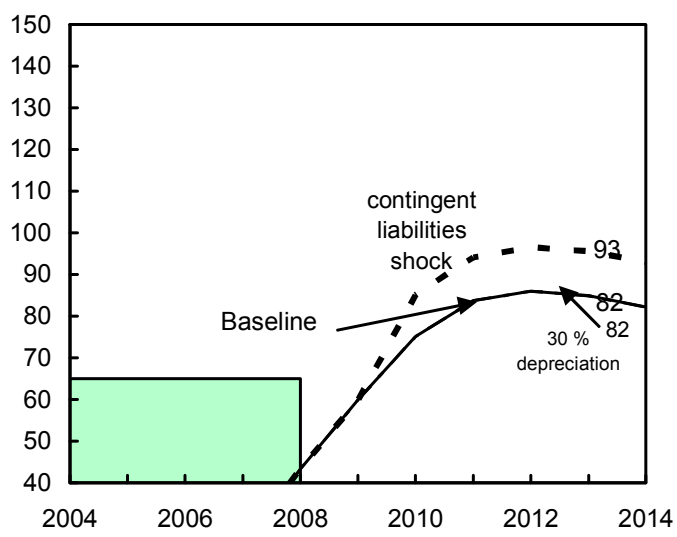

Sources: International Monetary Fund, country desk data, and staff estimates.

1/ Shaded areas represent actual data. Individual shocks are permanent one-half standard deviation shocks. Figures in the boxes represent average projections for the respective variables in the baseline and scenario being presented. Ten-year historical average for the variable is also shown.

2/ Permanent 1/4 standard deviation shocks applied to real interest rate, growth rate, and primary balance.

$3 /$ One-time real depreciation of 30 percent and 10 percent of GDP shock to contingent liabilities occur in 2009 , with real depreciation defined as nominal depreciation (measured by percentage fall in dollar value of local currency) minus domestic inflation (based on GDP deflator). 
Table A1. Ireland: Public Sector Debt Sustainability Framework, 2004-2014

(In percent of GDP, unless otherwise indicated)

\begin{tabular}{|c|c|c|c|c|c|c|c|c|c|c|c|c|}
\hline & \multicolumn{5}{|c|}{ Actual } & \multicolumn{6}{|c|}{ Projections } & \multirow{3}{*}{$\begin{array}{c}\text { Debt-stabilizing } \\
\text { primary } \\
\text { balance } 9 /\end{array}$} \\
\hline & 2004 & 2005 & 2006 & 2007 & 2008 & 2009 & 2010 & 2011 & 2012 & 2013 & 2014 & \\
\hline & & & & & & & & & & & & \\
\hline Baseline: Public sector debt $1 /$ & 29.4 & 27.3 & 24.7 & 24.8 & 43.2 & 59.9 & 75.0 & 83.7 & 86.0 & 84.8 & 82.2 & 0.7 \\
\hline Of which: foreign-currency denominated & 0.0 & 0.0 & 0.0 & 0.0 & 0.0 & 0.0 & 0.0 & 0.0 & 0.0 & 0.0 & 0.0 & \\
\hline Change in public sector debt & -1.6 & -2.2 & -2.6 & 0.1 & 18.5 & 16.7 & 15.1 & 8.7 & 2.3 & -1.1 & -2.7 & \\
\hline Identified debt-creating flows $(4+7+12)$ & -3.4 & -3.9 & -5.3 & -2.0 & 7.8 & 16.7 & 15.1 & 8.7 & 4.7 & 1.2 & -1.5 & \\
\hline Primary deficit & -2.5 & -2.5 & -3.8 & -1.2 & 6.1 & 9.8 & 10.0 & 6.2 & 3.1 & 0.2 & -2.3 & \\
\hline Revenue and grants & 34.3 & 34.5 & 36.1 & 35.1 & 32.9 & 32.9 & 32.7 & 34.9 & 35.2 & 35.4 & 35.4 & \\
\hline Primary (noninterest) expenditure & 31.8 & 31.9 & 32.3 & 33.9 & 39.0 & 42.6 & 42.6 & 41.1 & 38.3 & 35.6 & 33.1 & \\
\hline Automatic debt dynamics $2 /$ & -0.9 & -1.4 & -1.4 & -0.8 & 1.7 & 6.9 & 5.2 & 2.5 & 1.6 & 1.0 & 0.7 & \\
\hline Contribution from interest rate/growth differential 3/ & -0.9 & -1.4 & -1.4 & -0.8 & 1.7 & 6.9 & 5.2 & 2.5 & 1.6 & 1.0 & 0.7 & \\
\hline Of which: contribution from real interest rate & 0.5 & 0.4 & 0.0 & 0.6 & 1.1 & 2.8 & 3.3 & 3.3 & 3.5 & 3.1 & 2.9 & \\
\hline Of which: contribution from real GDP growth & -1.4 & -1.7 & -1.4 & -1.4 & 0.6 & 4.1 & 1.9 & -0.7 & -1.9 & -2.1 & -2.1 & \\
\hline Contribution from exchange rate depreciation $4 /$ & 0.0 & 0.0 & 0.0 & 0.0 & 0.0 & $\ldots$ & $\ldots$ & $\ldots$ & $\ldots$ & $\ldots$ & $\ldots$ & \\
\hline Other identified debt-creating flows & 0.0 & 0.0 & 0.0 & 0.0 & 0.0 & 0.0 & 0.0 & 0.0 & 0.0 & 0.0 & 0.0 & \\
\hline Privatization receipts (negative) & 0.0 & 0.0 & 0.0 & 0.0 & 0.0 & 0.0 & 0.0 & 0.0 & 0.0 & 0.0 & 0.0 & \\
\hline Recognition of implicit or contingent liabilities & 0.0 & 0.0 & 0.0 & 0.0 & 0.0 & 0.0 & 0.0 & 0.0 & 0.0 & 0.0 & 0.0 & \\
\hline Other (specify, e.g. bank recapitalization) & 0.0 & 0.0 & 0.0 & 0.0 & 0.0 & 0.0 & 0.0 & 0.0 & 0.0 & 0.0 & 0.0 & \\
\hline Residual, including asset changes (2-3) $5 /$ & 1.8 & 1.7 & 2.7 & 2.0 & 10.7 & 0.0 & 0.0 & 0.0 & -2.4 & -2.3 & -1.1 & \\
\hline Public sector debt-to-revenue ratio $1 /$ & 85.8 & 79.1 & 68.4 & 70.6 & 131.2 & 182.2 & 229.5 & 239.9 & 244.4 & 239.8 & 232.4 & \\
\hline Gross financing need $6 /$ & -1.4 & -1.5 & -2.9 & -0.2 & 7.1 & 11.8 & 12.7 & 9.4 & 6.7 & 3.9 & 1.4 & \\
\hline In billions of U.S. dollars & -2.6 & -3.0 & -6.6 & -0.6 & 19.5 & 27.0 & 28.0 & 21.2 & 15.5 & 9.4 & 3.4 & \\
\hline Scenario with key variables at their historical averages $7 /$ & & & & & & 59.9 & 55.2 & 50.8 & 44.5 & 38.6 & 33.9 & -1.5 \\
\hline Scenario with no policy change (constant primary balance) in 2009-2014 & & & & & & 59.9 & 74.8 & 87.1 & 96.1 & 104.6 & 114.2 & 1.0 \\
\hline \multicolumn{13}{|l|}{ Key Macroeconomic and Fiscal Assumptions Underlying Baseline } \\
\hline Real GDP growth (in percent) & 4.7 & 6.4 & 5.7 & 6.0 & -2.3 & -8.5 & -3.0 & 1.0 & 2.3 & 2.6 & 2.6 & \\
\hline Average nominal interest rate on public debt (in percent) $8 /$ & 3.9 & 3.8 & 3.5 & 4.2 & 4.2 & 4.3 & 4.4 & 4.4 & 4.4 & 4.4 & 4.4 & \\
\hline Average real interest rate (nominal rate minus change in GDP deflator, in percent) & 1.8 & 1.5 & 0.1 & 2.8 & 4.5 & 6.0 & 5.4 & 4.4 & 4.3 & 3.8 & 3.5 & \\
\hline Nominal appreciation (increase in U.S. dollar value of local currency, in percent) & 9.9 & 0.2 & 0.8 & 9.2 & 7.3 & $\ldots$ & $\ldots$ & $\ldots$ & $\ldots$ & $\ldots$ & $\ldots$ & \\
\hline Inflation rate (GDP deflator, in percent) & 2.0 & 2.3 & 3.4 & 1.4 & -0.3 & -1.7 & -1.0 & 0.0 & 0.2 & 0.7 & 0.9 & \\
\hline Growth of real primary spending (deflated by GDP deflator, in percent) & 5.6 & 7.0 & 6.9 & 11.2 & 12.6 & -0.1 & -2.9 & -2.8 & -4.6 & -4.6 & -4.6 & \\
\hline Primary deficit & -2.5 & -2.5 & -3.8 & -1.2 & 6.1 & 9.8 & 10.0 & 6.2 & 3.1 & 0.2 & -2.3 & \\
\hline
\end{tabular}

Sources: Central Statistics Office, Department of Finance, and IMF staff calculations.

$1 /$ Indicate coverage of public sector, e.g., general government or nonfinancial public sector. Also whether net or gross debt is used.

2/ Derived as $[(r-p(1+g)-g+a e(1+r)] /(1+g+p+g p))$ times previous period debt ratio, with $r=$ interest rate; $p=$ growth rate of GDP deflator; $g=$ real GDP growth rate; $a=$ share of foreign-currency denominated debt; and $\mathrm{e}=$ nominal exchange rate depreciation (measured by increase in local currency value of U.S. dollar).

3 / The real interest rate contribution is derived from the denominator in footnote $2 /$ as $r-\pi(1+g)$ and the real growth contribution as $-g$.

$4 /$ The exchange rate contribution is derived from the numerator in footnote $2 /$ as ae( $1+r)$.

$5 /$ For projections, this line includes exchange rate changes.

6/ Defined as public sector deficit, plus amortization of medium and long-term public sector debt, plus short-term debt at end of previous period.

7/ The key variables include real GDP growth; real interest rate; and primary balance in percent of GDP.

8/ Derived as nominal interest expenditure divided by previous period debt stock.

9/ Assumes that key variables (real GDP growth, real interest rate, and other identified debt-creating flows) remain at the level of the last projection year. 
Table A2. Ireland: Net Investment Position (In percent of GDP)

\begin{tabular}{|c|c|c|c|c|c|c|c|c|}
\hline & 2000 & 2001 & 2002 & 2003 & 2004 & 2005 & 2006 & 2007 \\
\hline Assets & 649 & 727 & 712 & 775 & 866 & 1,037 & 1,135 & 1,190 \\
\hline Direct investment abroad & 29 & 40 & 43 & 42 & 53 & 54 & 52 & 52 \\
\hline Portfolio investment abroad & 350 & 420 & 420 & 474 & 528 & 618 & 694 & 702 \\
\hline Other investment abroad & 265 & 262 & 245 & 257 & 284 & 364 & 389 & 435 \\
\hline Reserve assets & 6 & 5 & 4 & 2 & 1 & 0 & 0 & 0 \\
\hline Liabilities & 657 & 742 & 730 & 795 & 884 & 1,062 & 1,140 & 1,206 \\
\hline Direct investment to Ireland & 130 & 130 & 134 & 127 & 102 & 85 & 67 & 69 \\
\hline Portfolio investment to Ireland & 296 & 352 & 343 & 389 & 484 & 633 & 690 & 697 \\
\hline Other investment to Ireland & 230 & 260 & 253 & 280 & 298 & 343 & 383 & 440 \\
\hline Net investment position & -8 & -15 & -18 & -20 & -18 & -25 & -5 & -16 \\
\hline Direct investment, net & -102 & -90 & -91 & -85 & -50 & -31 & -15 & -17 \\
\hline Portfolio investment, net & 54 & 68 & 77 & 85 & 45 & -15 & 4 & 5 \\
\hline Other investment, net & 34 & 2 & -8 & -23 & -14 & 21 & 6 & -5 \\
\hline Reserve assets & 6 & 5 & 4 & 2 & 1 & 0 & 0 & 0 \\
\hline \multicolumn{9}{|l|}{ Memorandum items } \\
\hline Net investment position (excl. FDI) & 94 & 75 & 73 & 65 & 32 & 6 & 10 & 0 \\
\hline Change in net investment position & -58.5 & -7.3 & -2.7 & -2.2 & 2.1 & -6.6 & 19.3 & -11.2 \\
\hline Of which: c urrent account balance & -0.4 & -0.6 & -1.0 & 0.0 & -0.6 & -3.5 & -3.6 & -5.4 \\
\hline Other 1/ & -58.1 & -6.6 & -1.7 & -2.2 & 2.7 & -3.1 & 22.9 & -5.8 \\
\hline
\end{tabular}

Source: Central Statistics Office.

$1 /$ Includes valuation changes and errors and omissions. 


\section{INTERNATIONAL MONETARY FUND}

\section{IRELAND}

\section{Staff Report for the 2009 Article IV Consultation-Informational Annex}

\section{Prepared by the European Department}

May 20, 2009

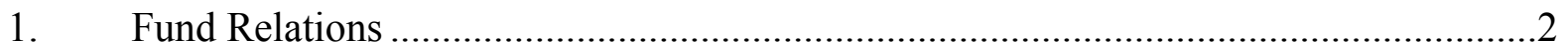

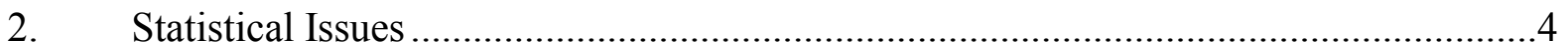




\section{Annex I. Ireland: Fund Relations}

(As of April 30, 2009)

I. Membership Status: Joined 8/08/57; Article VIII

II. General Resources Account:

Quota

Fund holdings of currency

Reserve position in Fund

$\begin{array}{cc}\text { SDR Million } & \text { Percent of Quota } \\ 838.40 & 100.00 \\ 732.12 & 87.32 \\ 106.29 & 12.68\end{array}$

Holdings Exchange Rate

III. SDR Department:

SDR Million Percent of Allocation

Net cumulative allocation

87.26

100.00

Holdings

63.82

73.13

IV. Outstanding Purchases and Loans: None

V. Financial Arrangements: None

VI. Projected Payments to the Fund (SDR million; based on existing use of resources and present holdings of SDRs):

\begin{tabular}{lccccc} 
& \multicolumn{5}{c}{ Forthcoming } \\
\cline { 2 - 6 } & $\mathbf{2 0 0 9}$ & $\mathbf{2 0 1 0}$ & $\mathbf{2 0 1 1}$ & $\mathbf{2 0 1 2}$ & $\mathbf{2 0 1 3}$ \\
$\begin{array}{l}\text { Principal } \\
\text { Charges/Interest } \\
\text { Total }\end{array}$ & $\underline{0.08}$ & $\underline{0.10}$ & $\underline{0.10}$ & $\underline{0.10}$ & $\underline{0.10}$ \\
& 0.08 & 0.10 & 0.10 & 0.10 & 0.10
\end{tabular}

\section{Article IV Consultations:}

A staff team comprising Mr. Mody (head), Mr. Kanda, Ms. Athanasapolou (all EUR), Messrs. Seelig and Darbar (both MCM), and Ms. Luedersen (LEG) visited Dublin on April 20-May 1, 2009, to conduct the 2009 Article IV consultation discussions. Mr. Horgan, Mr. O'Sullivan, and Mr. McGoldrick, from the Executive Director's office, joined the discussions.

The last Article IV consultation was concluded on September 14, 2007 (IMF Country Report No. 07/325). Article IV consultations with Ireland are on the standard 12-month cycle.

\section{Exchange Rate Arrangement and Exchange Restrictions}

Ireland's currency is the euro, which floats freely and independently against other currencies. 
Ireland has accepted the obligations of Article VIII, Sections 2, 3, and 4, and maintains an exchange system free of restrictions on payments and transfers for current international transactions, other than restrictions notified to the Fund under Decision No. 144 (52/51).

IX. Technical Assistance: None

X. Resident Representative: None 


\section{Annex II. Ireland: Statistical Issues}

1. Ireland is subject to the statistical requirements and timeliness and reporting standards of Eurostat and the European Central Bank (ECB). It has also subscribed to the Fund's Special Data Dissemination Standard (SDDS).

2. The consumer price index is published monthly. The weights were updated in 2006, and are to be updated every five years. Quarterly national accounts are currently published within three months of its reference period. Real sector data are sometimes published with a lag of three to six months, but some non-SDDS series even one and a half years later (e.g., household disposable income). Employment, earnings, unit wage costs, and national income and expenditure data are usually available with a three-month lag. Ireland does not have an overall earnings index or comprehensive sectoral balance sheet data.

3. While the authorities publish Exchequer returns on a monthly and quarterly basis, only annual data on the general government balance are currently available. Data for 1997 are the latest data submitted and published in the GFS Yearbook, while the latest central government data submitted for inclusion in the IFS were for the second quarter of 2003.

4. Quarterly balance of payments data are compiled by the Central Statistics Office and are based on statistical surveys combined with administrative data. These data are closely integrated with the compilation of national accounts and are in line with the Balance of Payments Manual, $5^{\text {th }}$ edition (BPM5), although the historical data covers only years starting from 1998. Furthermore, some discrepancies remain between exports and imports data from the national accounts and the balance of payments. 
Ireland: Table of Common Indicators Required for Surveillance

(as of May 6, 2009)

\begin{tabular}{|l|c|c|c|c|c|}
\hline & $\begin{array}{c}\text { Date of } \\
\text { Latest } \\
\text { Observation }\end{array}$ & $\begin{array}{c}\text { Date } \\
\text { Received }\end{array}$ & $\begin{array}{c}\text { Frequency } \\
\text { of } \\
\text { Data }\end{array}$ & $\begin{array}{c}\text { Frequency } \\
\text { of } \\
\text { Reporting }^{6}\end{array}$ & $\begin{array}{c}\text { Frequency } \\
\text { of } \\
\text { Publication }^{6}\end{array}$ \\
\hline Exchange Rates & $5 / 6 / 09$ & $5 / 6 / 09$ & $\mathrm{D}$ & $\mathrm{D}$ & $\mathrm{D}$ \\
\hline $\begin{array}{l}\text { International Reserve Assets and Reserve } \\
\text { Liabilities of the Monetary Authorities }\end{array}$ & March 2009 & $04 / 30 / 09$ & $\mathrm{M}$ & $\mathrm{M}$ & $\mathrm{M}$ \\
\hline Reserve/Base Money & March 2009 & $04 / 30 / 09$ & $\mathrm{M}$ & $\mathrm{M}$ & $\mathrm{M}$ \\
\hline Broad Money & March 2009 & $04 / 30 / 09$ & $\mathrm{M}$ & $\mathrm{M}$ & $\mathrm{M}$ \\
\hline Central Bank Balance Sheet & March 2009 & $04 / 30 / 09$ & $\mathrm{M}$ & $\mathrm{M}$ & $\mathrm{M}$ \\
\hline $\begin{array}{l}\text { Consolidated Balance Sheet of the Banking } \\
\text { System }\end{array}$ & March 2009 & $04 / 30 / 09$ & $\mathrm{M}$ & $\mathrm{M}$ & $\mathrm{M}$ \\
\hline Interest Rates & & & $\mathrm{D}$ & $\mathrm{D}$ \\
\hline Consumer Price Index & $5 / 6 / 09$ & $5 / 6 / 09$ & $\mathrm{D}$ & $\mathrm{D}$ & $\mathrm{M}$ \\
\hline $\begin{array}{l}\text { Revenue, Expenditure, Balance and Composition } \\
\text { of Financing }\end{array}$ - General Government
\end{tabular}

${ }^{1}$ Includes reserve assets pledged or otherwise encumbered as well as net derivative positions.

${ }^{2}$ Both market-based and officially-determined, including discount rates, money market rates, rates on treasury bills, notes and bonds.

${ }^{3}$ Foreign, domestic bank, and domestic nonbank financing.

${ }^{4}$ The general government consists of the central government (budgetary funds, extra budgetary funds, and social security funds) and state and local governments.

${ }^{5}$ Including currency and maturity composition.

${ }^{6}$ Daily (D), Weekly (W), Monthly (M), Quarterly (Q), Annually (A); Not Available (NA). 
Public Information Notice (PIN) No. 09/79

FOR IMMEDIATE RELEASE

June 24, 2009

International Monetary Fund $70019^{\text {th }}$ Street, NW

Washington, D. C. 20431 USA

\section{IMF Executive Board Concludes 2009 Article IV Consultation with Ireland}

On June 15, 2009, the Executive Board of the International Monetary Fund (IMF) concluded the Article IV consultation with Ireland. ${ }^{1}$

\section{Background}

Following years as a star performer, Ireland is undergoing a painful adjustment as critical internal imbalances unwind. Since the start of the decade, and especially from 2005 to 2007, easy credit fostered a property bubble, bank exposures to property lending soared while reliance on wholesale funding intensified, wages rose rapidly, and international competitiveness was compromised.

GDP grew in 2007 at a brisk 6 percent. However growth began to slow early in 2008 with a deceleration in housing construction, even while parts of the eurozone, notably Germany, were still in the last phases of the previous up cycle. As elsewhere, the pace of contraction accelerated following the failure of Lehman Brothers in September. Recent data point to further deceleration in 2009.

The banking system is under considerable stress as asset quality-especially that related to property development - has deteriorated and the global financial crisis has tightened access to wholesale

\footnotetext{
${ }^{1}$ Under Article IV of the IMF's Articles of Agreement, the IMF holds bilateral discussions with members, usually every year. A staff team visits the country, collects economic and financial information, and discusses with officials the country's economic developments and policies. On return to headquarters, the staff prepares a report, which forms the basis for discussion by the Executive Board. At the conclusion of the discussion, the Managing Director, as Chairman of the Board, summarizes the views of Executive Directors, and this summary is transmitted to the country's authorities.
} 
funding. Irish bank stock prices have fallen sharply relative to the overall stock index, more so than in other eurozone countries. Extensive support by the government has been vital to maintaining financial stability.

Strong growth and buoyant public revenues prompted tax reductions and expansion in public expenditures that have proved unsustainable. Following a decade of close-to-balance-or-surplus fiscal positions, the general government deficit was 7 percent of GDP in 2008 as property-related revenues collapsed. The structural deficit is estimated to have reached $12^{1 / 2} 2$ percent of GDP in 2008 . Gross public debt reached 43 percent of GDP. The authorities have taken a series of consolidation measures, and laid out a multi-year plan to restore the fiscal position to health.

\section{Executive Board Assessment}

Executive Directors noted that Ireland has been hit particularly hard by the global economic and financial crisis, reflecting significant vulnerabilities built up during the boom years, amplified by the openness of the economy to global shocks. Critical macroeconomic imbalances emerged as credit supply accommodated an unsustainable rise in property prices; banks' exposure to property lending soared while their reliance on wholesale funding intensified; and, as wages climbed rapidly, international competitiveness declined.

Directors agreed that the priorities are to restore the health of the financial sector, ensure the sustainability of the public finances, and enhance external competitiveness and the growth potential over the medium term. They commended the scale and speed of the authorities' response so far, while noting that these efforts will need to be sustained over an extended period of time. Pragmatic and flexible responses as well as careful contingency planning will be required given the complex policy dilemmas to be confronted and the prospect of only modest recovery ahead.

Directors welcomed the actions taken to safeguard financial stability, backed by ready access to European Central Bank financing. Noting that banking system losses are likely to be sizeable in the near term, Directors supported the authorities' efforts to restructure the financial sector, including the decision to establish the National Asset Management Agency (NAMA). Directors underscored the importance of adequate design and timely implementation of NAMA. They advised the authorities to consider risk-sharing structures to help deal with the problems with pricing distressed assets. In addition, NAMA should be given the legal and operational flexibility to address all classes of distressed bank assets. A number of Directors considered that, for bank restructuring, other options including a greater equity interest by the government should not be ruled out.

Directors welcomed recent plans to strengthen the supervisory framework, noting that the proposed macro-prudential supervisory framework will blend considerations of systemic stability with managing the stress in individual financial institutions. Directors recommended intensified bank-bybank surveillance beyond the banks currently under deposit guarantee, and stronger safeguards against related-party exposures. They also called for rigorous assessments of banks' overall capital adequacy, and for strengthened home-host supervisory cooperation. Directors considered that a 
special resolution regime for financial institutions would facilitate a speedy and less disruptive resolution of distressed banks.

Directors welcomed the fiscal measures already taken, including significant and politically difficult cuts in public sector wages, and the authorities' ambitious medium-term fiscal consolidation plans. The emergence of a large structural fiscal deficit-following the reassessment of the underlying balance - the rising public debt, and the fiscal burden from financial support to banks will require a sustained adjustment effort over several years. Directors stressed that the composition of consolidation efforts would be important in laying the foundation for a return to robust growth. They generally concurred that the focus should be on expenditure reduction, possibly including a further reduction of the public sector wage bill. A few Directors, while recognizing that fiscal consolidation is an imperative, cautioned that consolidation should not undermine efforts to arrest the economic downturn.

Directors considered that, over time, the sustainability of the planned fiscal consolidation would benefit from an effective institutional framework, including an appropriate fiscal rule and a medium-term expenditure plan that details the intended measures over the full planning horizon. They also underscored the importance of better targeting benefits for the vulnerable, broadening the tax base without hampering the restoration of external competitiveness, and further pension reform. A few Directors expressed concern about the use of resources of the National Pension Reserve Fund for bank recapitalizing purposes.

Directors stressed that economic growth will hinge on continued restoration of Ireland's international competitiveness and a reorientation of the economy toward high-productivity activities. They noted that, with no scope for nominal exchange rate adjustment, Ireland's relatively flexible product and labor markets will be an invaluable asset. They welcomed in this regard the authorities' commitment to the restoration of wage cost competitiveness - acknowledging the progress already underway - and their plans on infrastructure and R\&D investment. A few Directors cautioned, however, that falling nominal wages could impair domestic demand and accelerate deflation.

Public Information Notices (PINs) form part of the IMF's efforts to promote transparency of the IMF's views and analysis of economic developments and policies. With the consent of the country (or countries) concerned, PINs are issued after Executive Board discussions of Article IV consultations with member countries, of its surveillance of developments at the regional level, of postprogram monitoring, and of ex post assessments of member countries with longer-term program engagements. PINs are also issued after Executive Board discussions of general policy matters, unless otherwise decided by the Executive Board in a particular case. The staff report (use the free Adobe Acrobat Reader to view this pdf file) for the 2009 Article IV Consultation with Ireland is also available. 
Ireland: Selected Economic Indicators

\begin{tabular}{|c|c|c|c|c|c|c|}
\hline & 2003 & 2004 & 2005 & 2006 & 2007 & 2008 \\
\hline \multicolumn{7}{|l|}{ Real Economy (change in percent) } \\
\hline Real GDP & 4.5 & 4.7 & 6.4 & 5.7 & 6.0 & -2.3 \\
\hline Real GNP & 5.9 & 4.5 & 5.8 & 6.3 & 4.1 & -3.1 \\
\hline Domestic demand & 3.9 & 4.3 & 8.7 & 6.1 & 3.7 & -5.7 \\
\hline Exports of goods and services & 0.6 & 7.5 & 5.2 & 5.7 & 6.8 & -0.4 \\
\hline Imports of goods and services & -1.6 & 8.5 & 8.2 & 6.3 & 4.1 & -4.4 \\
\hline $\mathrm{HICP}$ & 4.0 & 2.3 & 2.2 & 2.7 & 2.9 & 3.1 \\
\hline Unemployment rate (in percent) & 4.7 & 4.5 & 4.4 & 4.4 & 4.5 & 6.1 \\
\hline \multicolumn{7}{|l|}{ Public Finances (percent of GDP) } \\
\hline General government balance & 0.3 & 1.4 & 1.5 & 2.9 & 0.2 & -7.1 \\
\hline Structural balance $1 /$ & -5.0 & -4.4 & -5.4 & -5.7 & -8.7 & -12.5 \\
\hline General government debt & 31.1 & 29.4 & 27.3 & 24.7 & 24.8 & 43.2 \\
\hline \multicolumn{7}{|l|}{$\begin{array}{l}\text { Money and Credit (end-period, percent } \\
\text { change) }\end{array}$} \\
\hline M3 2/ & 9.8 & 22.5 & 22.0 & 28.5 & 9.6 & -2.1 \\
\hline Private sector credit 3 / & 17.9 & 26.6 & 28.8 & 25.9 & 17.0 & 6.6 \\
\hline \multicolumn{7}{|l|}{ Interest rates (end-period) } \\
\hline Three-month treasury bill & 2.1 & 2.2 & 2.5 & 3.7 & 3.4 & 1.5 \\
\hline 10-year government bond yield & 4.6 & 3.7 & 3.3 & 4.0 & 4.5 & 4.4 \\
\hline \multicolumn{7}{|l|}{ Balance of Payments (percent of GDP) } \\
\hline Trade balance (goods and services) & 15.4 & 14.2 & 11.7 & 10.3 & 10.3 & 11.5 \\
\hline Current account & 0.0 & -0.6 & -3.5 & -3.6 & -5.4 & -4.5 \\
\hline Reserves (in billions of euros) & 3.3 & 2.1 & 0.7 & 0.7 & 0.6 & 0.7 \\
\hline \multicolumn{7}{|l|}{ Exchange Rate } \\
\hline Exchange rate regime & & & & & & \\
\hline Euros per U.S. dollar & 0.9 & 0.8 & 0.8 & 0.8 & 0.7 & 0.7 \\
\hline Nominal effective rate $(1999 Q 1=100)$ & 101.9 & 104.5 & 104.1 & 104.4 & 107.4 & 113.0 \\
\hline Real effective rate (1999Q1=100, CPI based) & 112.6 & 115.8 & 115.4 & 116.0 & 120.1 & 125.5 \\
\hline
\end{tabular}

Sources: Central Statistics Office; Department of Finance, Datastream and IMF International Financial Statistics.

$1 /$ In percent of potential GDP.

2/ The methodology used to compile M3 has been amended in line with Eurosystem requirements. Therefore, there is a break in the series.

3/ Adjusted change, which includes the effects of transactions between credit institutions and nonbank international financial companies and valuation effects arising from exchange rate movements. 